\title{
HOLOCENE AND LITTLE ICE AGE GLACIAL ACTIVITY IN THE MARBORÉ CIRQUE, MONTE PERDIDO MASSIF, CENTRAL SPANISH PYRENEES
}

José M. García-Ruiz (1), David Palacios (2), Nuria de Andrés (2), Blas L. ValeroGarcés (1), Juan I. López-Moreno (1), Yasmina Sanjuán (1)

(1) Instituto Pirenaico de Ecología, CSIC, Campus de Aula Dei, P.O. Box 13.034, 50080-Zaragoza, Spain.

(2) Department of Physical Geography, Universidad Complutense de Madrid, 28040Madrid, Spain.

\begin{abstract}
The Marboré Cirque, which is located in the southern central Pyrenees on the

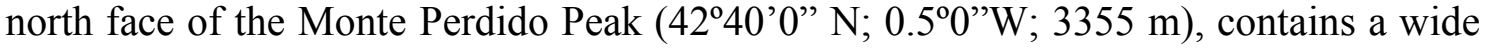
variety of Holocene glacial and periglacial deposits, and those from the Little Ice Age (LIA) are particularly well-developed. Based on geomorphological mapping, cosmogenic exposure dating and previous studies of lacustrine sediment cores, the different deposits were dated and a sequence of geomorphological and paleoenvironmental events was established as follows: (i) The Marboré Cirque was at least partially deglaciated before $12.7 \mathrm{ky}$ BP. (ii) Some ice masses are likely to have persisted in the Early Holocene, although their moraines were destroyed by the advance of glaciers during the Mid Holocene and LIA. (iii) A glacial expansion occurred during the Mid Holocene $(5.1 \pm 0.1 \mathrm{ka})$, represented by a large push moraine that enclosed a unique ice mass at the foot of the Monte Perdido Massif. (iv) A melting phase occurred at approximately $3.4 \pm 0.2$ and $2.5 \pm 0.1 \mathrm{ka}$ (Bronze/Iron Ages) after one of the most important glacial advances of the Neoglacial period. (v) Another glacial expansion occurred during the Dark Age Cold Period (1-4-1.2 ka), followed by a melting period during the Medieval Climate Anomaly. (vi) The LIA represented a clear stage of glacial expansion within the Marboré Cirque. Two different pulses of glaciation were detected, separated by a short retraction. The first pulse occurred most likely during the late 17 th century or early 18th century (Maunder Minimum), whereas the second occurred between 1790 and 1830 AD (Dalton Minimum). A strong deglaciation process has affected the Marboré Cirque glaciers since the middle of the 19th century. (vii) A large
\end{abstract}


rock avalanche occurred during the Mid Holocene, leaving a chaotic deposit that was previously considered to be a Late Glacial moraine.

Key words: Holocene glaciers, Little Ice Age, Rock avalanche, Cosmogenic exposure ages, Marboré Cirque, Central Pyrenees.

\section{Introduction}

The study and mapping of recent morainic deposits related to climatic fluctuations during the Holocene, particularly the Little Ice Age (LIA), can reveal the the extent and spatial variability of the ice masses during the last millennia and how they correlate with climate and environmental changes. A good comprehension of glacial events is key to understanding the changes that have recently affected mountainous areas (e.g., the temperature increases over the last two centuries) and the importance of topographic and climatic factors in the development of small glaciers.

Studies on Pleistocene glaciations have generally ignored the climate shifts of the Holocene, which is generally believed to have had a mild, almost stationary climate (Clague et al., 2009). Nevertheless, abrupt, sometimes large climate changes have occurred since the onset of the Holocene, ca. 11,700 yr BP (Marcott et al., 2013), causing remarkable glacial expansions and contractions (Bond et al., 1997; Mayewski et al., 2004; Deline and Orombelli, 2005; Clague et al., 2009; Davis et al., 2009; Wanner et al., 2011), changing the characteristics of vegetation (Magny et al., 2002; Fletcher et al., 2010; Jalut et al., 2009) and altering natural resources in ways that have had local effects on the patterns of human occupation (González-Sampériz et al., 2009). It has been demonstrated that mountain glaciers worldwide reacted rapidly to changes in precipitation and/or temperature during the Holocene, but the timing and causes of these changes remain unclear (Davis et al., 2009).

During the past few decades, Holocene climate and glacier fluctuations have been intensively studied for most mountains worldwide, particularly those in Europe (e.g., Jalut et al., 2000; Deline and Orombelli, 2005; Holzhauser et al., 2005; Bakke et al., 2010; Nesje, 2009) and North America (e.g. Clague et al., 2009; Menounos et al., 2009). In the case of the Iberian mountains, particular attention has been paid to the moraines of the Little Ice Age (LIA) (González Trueba et al., 2008). The southern latitude of the Iberian Peninsula explains why the LIA glaciers were relatively small and restricted to the high peaks in the Central Pyrenees, Picos de Europa in the Cantabrian 
Range, and Sierra Nevada in the extreme south (González Trueba et al., 2008). The central Pyrenees had the highest number of glaciers during the LIA, especially at altitudes $>3000 \mathrm{~m}$. Many of these glaciers have disappeared during the last four decades, and the extent of the remaining glaciers has been greatly reduced (Chueca et al., 2002). Nevertheless, many moraines have been associated with the glacial expansions of the LIA, allowing reconstruction of the LIA sizes of most glaciers. The information provided by Schrader (1894) indicates that the LIA glaciers occupied 3366 ha of the Pyrenees in 1876. However, we do not have any data on glaciation in the Iberian Peninsula during most of the Holocene.

The lack of information on glacial evolution during the Holocene (except for the LIA) contrasts with an increasing number of lacustrine Holocene records available from the Iberian Peninsula (Corella et al., 2011; Moreno et al., 2011; Morellón et al., 2012; Oliva and Gómez Ortiz, 2012). Collectively, these studies have demonstrated the existence of important environmental changes throughout the Holocene. The glacial response to this climate variability is unknown.

The area with the highest variety of recent morainic deposits in the Pyrenees is the Marboré Cirque. Located in the northern side of the Monte Perdido Massif, within the Ordesa and Monte Perdido National Park (OMPNP), the Marboré Cirque retains some active glaciers and has abundant and well-preserved glacial deposits. Recently, a sediment record obtained from a lake inside the cirque has reconstructed the depositional evolution of the alpine lake during the Holocene (Oliva-Urcia et al., 2013). The Marboré Cirque is very close to the Troumouse Cirque (French Pyrenees), where an important intra-Holocene advance was detected (Gellatly et al., 1992). Thus, the Marbore Cirque is a taget area to study glacial evolution in the Pyrenees during the Holocene.

The main purposes of this paper are to study and date the sequence of paleoenvironmental events represented in the deposits of the Marboré Cirque, to differentiate the LIA deposits from other possible Holocene deposits, and to reconstruct the extent and evolution of the ice masses at various moments during the recent millennia.

\section{The study area}

The Marboré Cirque (Fig. 1) forms a basin of $5.8 \mathrm{~km}^{2}$ at the foot of the northern face of the Monte Perdido Massif (Central Pyrenees, Spain). The cirque is bounded to 
the north by the Tucarroya Crest and the Astazu Peak $(3071 \mathrm{~m})$, to the west by the Pequeño Occidental Peak (3013 m), and to the south by a dramatic wall composed of the Monte Perdido (3355 m), Cilindro (3322 m) and Marboré (3247 m) peaks. This wall comprises a vertical cliff of 500-800 m height, with several secondary scarps composed of different Cretaceous and Tertiary rock formations. At the base of the wall, the Cinca River flows from the glaciers themselves, carving a longitudinal basin from west to east. Toward the east, the cirque opens to the Pineta glacier Valley, with an abrupt loss of altitude (ca. $1000 \mathrm{~m}$ ). The cirque altitude progressively ascends from the eastern border at $2520 \mathrm{~m}$ asl (called the Balcón de Pineta) towards the west. In the northern part of the cirque (i.e. at the foot of the Tucarroya Crest and the Astazu Peak), there is a narrow longitudinal depression where the Marboré Lake is located (2595 m asl). The Marboré Cirque and Monte Perdido Massif have been part of the OMPNP since 1981.

The Monte Perdido Massif is part of the Inner Sierras, which form a main structural unit of the southern Pyrenees. The rock formations exposed in the Inner Sierras correspond to Cretaceous-Eocene limestone, marly limestone and sandstone. The compressive structural style is characterized by the stacking of south-verging thrust sheets emplaced during the Alpine orogeny. Three morphostructural units can be distinguished in the Marboré Cirque:

(i) The Marboré Cirque has a clear structural control and it is located in a synclinorium-like structure, wherein alternating limestone and sandstone outcrops evolve towards cuestas, which become almost vertical at the extreme north of the cirque (i.e., at the Tucarroya Crest and Astazu Peak). The sandstone and limestone formations have been intensely affected by chemical and physical weathering, generating a series of small cuestas lined up WSW-ESW, with the scarps facing north. Structural karren (kluftkarren) are present, mainly due to the solutional widening of the stratification planes and joints, with solution flutes (rillenkarren) prevailing on steep slopes. Small dolines and chasms are also relatively common.

(ii) The south margin of the cirque is an abrupt and complex wall forming the northern faces of the Monte Perdido, Cilindro and Marboré peaks carved in several overthrusting folded units. Maastrichtian sandstone dominates in the western part of the cliff (Marboré), whereas Eocene limestone prevails in the eastern part (Monte Perdido), although the lower part of the cliff also has a large sandstone outcropping.

(iii) In the middle of the cirque a dome at $2720 \mathrm{~m}$ asl, separates the longitudinal depression of the Marboré Lake and the basin where the Cinca River flows (i.e., at the 
foot of the Monte Perdido, Cilindro and Marboré peaks). This dome is called the Central Threshold.

According to Del Barrio et al. (1990), the actual $0^{\circ} \mathrm{C}$ isotherm is located at 2726 m. Feuillet and Mercier (2012) established the $0^{\circ} \mathrm{C}$ isotherm at approximately $2650 \mathrm{~m}$, noting that the mean annual temperature is $-1.3^{\circ} \mathrm{C}$ on the Midi de Bigorre Peak $(2877$ $\mathrm{m})$. To the east, in the Maladeta Glacier, the Equilibrium Line Altitude (ELA) is located between 2956 and $2959 \mathrm{~m}$; in 1820-1830, it was estimated to lie about $255 \mathrm{~m}$ lower than that (Chueca Cía et al., 2005). The mean annual precipitation is approximately $2015 \mathrm{~mm}$ in the Marboré Lake (Del Valle, 1997).

\section{Methods}

The recent glacier evolution in the Marboré Cirque has been reconstructed using several methodologies: (i) reviewing all information available from historical sources and previous works; (ii) performing detailed geomorphological mapping; (iii) analyzing some basic sediment characteristics; and (iv) cosmogenic dating of exposed surfaces.

A number of travellers crossed the Marbore Cirque since the end of the 18th century and during the 19th century; they described in detail the presence and extent of glaciers providing evidence of glacial evolution. In addition, scientific studies have been carried out since the end of the 19th century. An analysis of these documentary sources provided the framework for understanding the glacial evolution during the LIA, and helped us select the sampling sites for cosmogenic dating.

For geomorphological mapping, we identified morainic and periglacial deposits using the 1956 and 1982 aerial photographs and 2006 orthophotos. The survey was complemented by fieldwork during the summers of 2010, 2011 and 2012. In 2011, three generations of moraines were sampled and assessed for their grain-size distributions and carbonate contents. In 2012, an exhaustive search for polished or striated surfaces led to the identification of a few well-preserved sites with glacial erosion, which could be used for dating.

The moraine deposits did not contain organic carbon for ${ }^{14} \mathrm{C}$ dating, and the presence of quartz or feldspar was too limited for Optically Stimulated Luminiscence (OSL) methods. Since the thresholds and boulders are composed of limestone or calcareous sandstone, we decided to use the ${ }^{36} \mathrm{Cl}$ isotope to date how long the polished bedrocks and boulders had been exposed to cosmic radiation. 
Cosmogenic ${ }^{36} \mathrm{Cl}$ is produced in carbonates by several mechanisms, including: (i) fast neutron spallation on ${ }^{40} \mathrm{Ca}$; (ii) absorption of epithermal and thermal neutrons by ${ }^{35} \mathrm{Cl}$; and (iii) the capture of slow negative muons on ${ }^{40} \mathrm{Ca}$ (Phillips et al. 2001). Furthermore, the cosmogenic production rates of ${ }^{36} \mathrm{Cl}$ are much higher than those of other cosmogenic isotopes (Gosse and Pillips, 2001), making cosmogenic ${ }^{36} \mathrm{Cl}$ the most suitable isotope for dating limestone surfaces.

The geomorphological map was used to select sampling sites for ${ }^{36} \mathrm{Cl}$ surfaceexposure dating. Samples were collected from three glacial bedrock outcropings. The selection criteria were: (i) the sampling points were not glaciated during the LIA, according to our review of the historical sources and previous studies; (ii) they had a protrusive morphology that minimized the chance of a previous burial by soil, sediment or snow; (iii) they had a clear glacial polish, indicating no erosion after deglaciation; and (iv) they had been polished by a glacier that was thick enough to erode the preglacial surface (thus minimizing the chance of ${ }^{36} \mathrm{Cl}$ inheritance). Samples were also taken from two boulders representing an external deposit of grey limestone, and one from the outermost moraine, which was composed of white Eocene limestone. The selected boulders were large $(>1 \mathrm{~m} \times 1 \mathrm{~m} \times 1 \mathrm{~m})$, located on the crest of prominent deposit ridges (to reduce the chance of previous burial by soil, sediment or snow), and found on a stable part of the deposit (in order to minimize the chance of the boulder overturning or breaking). The monthly snow cover and the degree of erosion were estimated in the field, and these values were used as corrections during the age calculations.

Samples were analysed following the procedures described by Phillips (2003) and Zreda et al. (1999). Briefly, each rock sample were pulverized in a roller grinder, and then dissolved in a hot mixture of hydrofluoric acid and nitric acid, spiked with isotopically enriched ${ }^{35} \mathrm{Cl}$. Each sample was then $\mathrm{Cl}$ - precipitated as $\mathrm{AgCl}$, and AMS was used to measure the ${ }^{36} \mathrm{Cl} / \mathrm{Cl}$ and ${ }^{37} \mathrm{Cl} /{ }^{35} \mathrm{Cl}$ ratios of the $\mathrm{AgCl}$ targets (PRIME Lab, Purdue University). The total $\mathrm{Cl}$ content was determined by isotope dilution mass spectrometry; aliquots of rocks were powdered and analysed for major elements by fusion inductively coupled plasma; trace elements were examined by mass spectrometry; and boron was measured (all at PGNAA; Activation Laboratories, Canada).

The exposure ages were calculated with the CHLOE program version 3-2003 (Phillips and Plummer, 1996); we used the thermal and epithermal neutron distribution 
equations and ${ }^{36} \mathrm{Cl}$ production parameters applied in Phillips et al. (2001); the production of ${ }^{36} \mathrm{Cl}$ by muons reported by Stone et al. (1998); and the latitude and elevation scaling of production rates described by Lal (1991). For the CHLOE-based calculation of exposure ages we assumed rock surface erosion ratios of 0 (no erosion), 3 and $5 \mathrm{~mm} / \mathrm{ka}$. The applied snow cover value was based on the present snow dynamics.

\section{Results}

A) The glacial evolution of the Marboré Cirque according to historical sources

The Marboré Cirque was the highest cirque of the Cinca Glacier, which was approximately $24 \mathrm{~km}$ in length at its maximum extent, making it one of the largest in the southern Pyrenees. Penck (1883) was the first to describe the Cinca glacier deposits corresponding to the Upper Pleistocene glacier, although its timing and maximum extent were not studied until recently (Martí-Bono and García-Ruiz, 1993; Lewis et al., 2009). The Local Last Glacial Maximum would have occurred at approximately $64 \pm 11$ ky BP (Lewis et al., 2009), similarly to other Pyrenean valleys and the northern Iberian Peninsula glaciers (García-Ruiz et al., 2013; Jiménez-Sánchez et al., 2013).

The first scientist to study the Marboré Cirque and its glaciers was Franz Schrader, who traversed and described the area between 1866 and 1924. In 1873, Schrader (1874) mapped the cirque at a scale of 1:40,000, delimiting the extent of the glaciers. He later generated two additional maps at 1:100,000 (Schrader, 1882-1892) and 1:20,000 (Schrader, 1914). The extent of glaciation had not changed significantly between the 1874 report and the subsequent maps, even though the map of 1914 was much more precise, with contour levels similar to modern maps. Figure 2 includes information on the distribution of moraine deposits related to the ice masses that were cited and mapped by Schrader.

According to the map of 1874, a small glacier occupied the base of the Tucarroya Crest and the Astazu Peak. The so-called Lake Glacier (near the Marboré Lake) was visited and described by Ramond de Carbonnières in 1797 (Bonaparte, 1891). In the southern part of the cirque, the map of 1874 describes a unique glacier (the Monte Perdido Glacier), at the foot of the large wall formed by the Monte Perdido, Cilindro and Marboré peaks. The map of 1914 divides the glacier into three ice masses, one from each of the peaks, with that of Monte Perdido extending furthest. The Monte Perdido Glacier continued towards the east, up to at least $2420 \mathrm{~m}$ asl. The Lake Glacier extended up to the Marboré Lake. The Central Threshold appeared to be ice-free. According to 
the map of 1874, the Monte Perdido Glacier covered a total of 388 ha, although this was most likely overestimated due to the presence of a large snow cover (Martínez de Pisón and Arenillas, 1988). In contrast, the Lake Glacier covered only 8 ha. Several descriptions from Ramond de Carbonnières (1801) are consistent with the spatial distribution of glaciers according to Schrader and the ice-free nature of the Central Threshold. Between 1880 and 1894 several authors noted that the Lake Glacier had disappeared (e.g., Degrange 1882), and the Monte Perdido Glacier had clearly retreated (Bonaparte, 1891). Photos taken between 1890 and 1910, most of them by anonymous contributors (Médiathéque de l'Architecture et du Patrimoine of the French Government), show a rapid retreat of the glacier front and the dead ice amidst boulder chaos in the westernmost part of the cirque, resulting in a thermokarst topography.

During the 20th century, the excellent conservation of a number of glacial deposits in the Marboré Cirque facilitated various studies aimed at determining the extent occupied by the ice during the LIA. Gómez de Llarena (1936) described the existence of two types of moraines, with the oldest running parallel to the north-facing slope of the cirque, while the others were located perpendicular to the oldest. Hernández-Pacheco and Vidal Box (1946) studied the same moraines and agreed with the interpretation of Gómez de Llarena (1936). Boyé (1952a) was the first to perform a detailed study of the main moraine of the Monte Perdido Glacier, which was erroneously considered as a protalus-rampart that developed due to block falls displaced over a snow and ice mantle towards the foot of the versant. Nicolás Martínez (1981) attributed a large accumulation of grey limestone boulders in the Balcón de Pineta to the Late Glacial period, and following Gómez de Llarena (1936), he considered them to be an external moraine. García-Ruiz and Martí-Bono (2001) performed a relief study of the OMPNP, including a geomorphological mapping of glacial deposits. They stated that the morainic ridges located in the southern half of the Marbore Cirque should correspond to the LIA, and identified the accumulation of grey limestone boulders as a supraglacial till that most likely belonged to the Late Glacial period. Martín Moreno (2004) attributed the accumulation of grey limestone boulders to the Late Glacial period, but noted that they could also possibly correspond to intra-Holocene advances. He proposed two glacial advance phases within the LIA, with different moraine deposits.

Recently, sediment cores from the Marboré Lake demonstrated that partial deglaciation of the Marboré Cirque occurred approximately 13 ka ago, as the Marboré Lake was ice-free 12,700 years ago (Oliva-Urcia et al., 2013) The sediment sequence is 
composed of laminated silts and shows a significant change in depositional environments around $5500 \mathrm{cal}$ yr BP. Cores from La Larri paleo-lake, located $3 \mathrm{~km}$ to the east of the Marboré Lake, revealed that the paleo-lake developed $>35$ ka ago when the valley was dammed by a lateral moraine of the Cinca Valley, and it was drained when the moraine was breached around 11 ka ago (Salazar-Rincón et al., 2013).

These previous works provide a framework for deglaciation in the Cinca Valley. First, the Marboré Cirque was at least partially deglaciated 13 ka ago, and no glacier has covered the Marboré Lake since then (Oliva-Urcia et al., 2013; Salazar-Rincón et al., 2013). Sedimentary analysis of the Marboré Lake cores indicates that a significant depositional change occurred in the middle of the Holocene, coinciding with the glacial advance in the Troumouse Cirque (Gellatly et al., 1992). Second, the previous studies differentiated three groups of morainic or pseudo-morainic deposits (Figure 3): (i) morainic ridges that run transverse to the north-facing slope of the cirque; (ii) longitudinal, more externally located moraines that present the glacial maximum during the LIA (Gómez de Llarena, 1936; Hernández-Pacheco and Vidal Box, 1946; Nicolás Martínez, 1981; Martínez de Pisón and Arenillas, 1988; García-Ruiz and Martí-Bono, 2001; Martín Moreno, 2004), and appear to have been affected by subsequent advances (Martín Moreno, 2004); and (iii) a more external complex of grey limestone boulders, located close to the Balcón de Pineta, considered of Late Glacial or intra-Holocene age, and interpreted as a moraine (Gómez de Llarena, 1936; Hernández-Pacheco and Vidal Box, 1946; Nicolás Martínez, 1981; Martínez de Pisón and Arenillas, 1988), a nival protalus rampart (Boyé, 1952a) and a supraglacial till (García-Ruiz and Martí-Bono, 2001).

\section{B) Geomorphological analysis of the Marboré Cirque}

The map presented in Figure 2 shows the distribution of moraines and other deposits in the Marboré Cirque. Except for a small deposit to the east of the Marboré Lake, all of the morainic ridges are located in the southern part of the cirque, at the foot of the large wall of the Monte Perdido, Cilindro and Marboré peaks. Several deposits can be distinguished:

(i) A large accumulation of grey limestone boulders in the Balcón de Pineta area (Fig. 3). This chaotic deposit is composed of blocks that frequently surpass $5 \mathrm{~m}$ in the $a$ axis without fine material; the boulders appear to be aligned on rocky crests, giving the (mistaken) impression of comprising several parallel morainic ridges. Lithologically, it 
is a very homogeneous deposit, with an almost absolute predominance of grey limestone blocks transported from the summit areas of the northern face of Monte Perdido Peak. The blocks do nbot present any angle erosion, polishing or striation, although this could be due to the rapid dissolution of the limestone surface. Notably, no other similar deposit has been found elsewhere the cirque.

A number of authors interpreted this deposit as a glacial moraine corresponding to the Late Glacial (Upper Pleistocene) (Nicolás Martínez, 1981; Martínez de Pisón and Arenillas Parra, 1988; García-Ruiz and Martí-Bono, 2001; Martín Moreno, 2004). However, a variety of arguments suggests that this deposit represents a large rock avalanche that felt from the northern side of the Monte Perdido Peak: (a) it lacks any fine matrix, even though it is located more externally than the other Marbore Cirque moraines, which include copious fine material; (b) it is unique for its structure and texture, with no other similar deposit in the Marboré Cirque; and (c) it is an extraordinarily homogeneous deposit exclusively dominated by grey limestone, which contrasts with the lithological diversity of the Monte Perdido wall (e.g., grey and white limestone, brown Maastrichtien sandstone). We propose that this deposit was emplaced as a rock avalanche that affected the middle part of the Monte Perdido cliff.

(ii) A long and narrow NW-SE morainic ridge that runs from the foot of the Marboré Peak towards the east-southeast, showing a well-defined form and an acute crest $20 \mathrm{~m}$ above the base (Fig. 4). This deposit is composed of two units: a basal matrix-supported Maastrichtien sandstone blocks, and a top, 2 m thick block-supported unit. The lower unit is a typical push moraine that was displaced by an ice mass, and the top unit represents the supraglacial till. The ridge decreases rapidly in height and appears to continue toward the east as a series of parallel narrow ridges that are primarily composed of white limestone blocks from the Monte Perdido Wall. The latter observation suggests that the materials from the Marboré, Cilindro and Monte Perdido peaks did not mix during the development of this moraine, and, consequently, when this long moraine was deposited, the glacier continuously occupied the southern half of the Marboré Cirque, extending towards the Cinca Valley.

(iii) Smaller moraines located behind the previously described main moraine indicate that the ice mass retreated and expanded again, in the form of individual ice tongues. Three glaciers can be distinguished: (a) the Western Glacier, which was located at the foot of the Marbore Peak, and bordered by a moraine that almost contacted the main morainic ridge; (b) the Central Glacier, which was located at the foot 
of the Cilindro Peak; and (c) the Eastern Glacier (generally called the Monte Perdido glacier), which was located at the foot of the Monte Perdido Peak, and it is considered the most important glacier in the Marboré Cirque. The Monte Perdido Glacier was delimited by a large moraine, which forms a massive hill from west to east (750 m long, $250 \mathrm{~m}$ wide, and $40 \mathrm{~m}$ high; Fig. 5). It is composed of a mixture of Maastrichtien and Palaeocene materials and includes copious fine matrix; this internal structure is more typical of a subglacial till, rather than a protalus rampart as claimed by Boyé (1952a). The Monte Perdido glacier extended to the right, and had a well-defined ice tongue whose front was visible from the Cinca Valley in the 19th century. The individuality of this glacier is confirmed by the presence of a clear lateral moraine to the left side, separating this glacier from the Cilindro Peak one.

(iv) A subsequent retreat and re-advance resulted in the development of smaller ice masses. The Central Glacier, located at the foot of the Cilindro Peak, issued a short tongue whose moraines advanced to surpass those of the previous stage, leaving a small perpendicular double ridge that resembles a fluted moraine. Simultaneously, a small arched frontal moraine developed at the foot of the Marboré Peak, and another moraine developed in the westernmost sector of the cirque; the latter deposit, mostly composed of Maastrichtien blocks and boulders without polished or striated surfaces, is interpreted as a protalus rampart.

The morphology of the large moraine of the Monte Perdido Glacier indicates that a relatively important sediment remobilization occurred after its deposition. The existence of fluting transverse to the deposit indicates a rapid and recent glacial readvance and the passage of ice over the moraine, leaving a thin layer of till. The dragging of blocks would have caused the development of furrows typical of fluted moraines (as pointed out by Martín Moreno, 2004). These furrows are also visible in the subglacial till deposited between the foot of the Monte Perdido wall and its moraine. Similarly, this advance would have deposited some small block-supported moraines.

A large accumulation of blocks without fine matrix forming several arcs and depressions caused by ice melting at the western end of the cirque is interpreted as a small, non-functional rock (or rock-covered) glacier developed.

Table 1 shows the grain-size distribution and carbonate contents of three glacial deposits: (i) the most external moraine; (ii) a moraine at the foot of the Cilindro Peak; and (iii) the large moraine at the foot of the Monte Perdido Peak. Their mean carbonate contents are $30.2 \%, 35.8 \%$ and $86.6 \%$, respectively. The grain size distribution of the 
matrix also distinguished the Monte Perdido moraine, with a greater proportion of clay (37.3\% versus $16.2 \%$ and $20.1 \%$ in the outer moraine and the Cilindro Peak moraine, respectively). The inner moraine of the Cilindro Peak contains a higher sand percentage. These local differences illustrate how Maastrichtien sandstone outcrops control the moraine compositions, as the Monte Perdido Moraine reflects the greater presence of limestone in the Monte Perdido Wall.

In the northern part of the Marboré Cirque the Lake Glacier did not leave any moraine deposit, probably because it calved into the Marboré Lake; however, polished and striated surfaces are visible in the areas that were directly affected by this glacier. At the end of the 20th century, small snow patches persisted in this region.

\section{C) Cosmogenic dating of the Marboré Cirque glacial landforms}

Six dates were obtained from the Marbore Cirque, three from polished surfaces and three from boulders (Table 2). Two polished surfaces close to the small Lake glacier at the foot of the Astazu Peak yielded dates of $3.4 \pm 0.2 \mathrm{ka}$ and $2.5 \pm 0.1 \mathrm{ka}$. (Fig. 6), while another polished surface at the outlet of the Marboré Lake yielded a date of $1.2 \pm 0.1 \mathrm{ka}$. Two samples from large boulders located in the grey limestone deposit of the Balcón de Pineta yielded dates of $2.5 \pm 0.05 \mathrm{ka}$ and $4.4 \pm 0.1 \mathrm{ka}$, whereas a boulder located in the white limestone moraine (outermost moraine) at the front of the Monte Perdido glacier yielded an age of $5.1 \pm 0.1 \mathrm{ka}$.

No other dates have been obtained from polished surfaces, moraines or other deposits of the Marboré Cirque, because weathering has intensively affected most of the deposits, and no adequate sites were found for sampling. The moraines behind the large outermost moraine undoubtedly belong to different stages of the LIA, given their fresh appearance and the absence of soil and vegetation. In fact, according to the map of Schrader from 1874 and other historical sources, the Monte Perdido Glacier made direct contact with the large moraine in the second half of the 19th century.

\section{Discussion}

The Marboré Cirque offers the best examples of Holocene glacial deposits in the Pyrenees and the Iberian Peninsula. No deposits corresponding to the Late Pleistocene have been found in the cirque, and there is sedimentological evidence that the Marbore Lake was deglaciated at least since the onset of the Holocene (Oliva-Urcia et al., 2013). The neighbouring La Larri Lake was dammed by a lateral moraine of the Cinca Glacier, 
which was probably related to the glacial advance phase at 39-32 ka (Lewis et al., 2009). The lake filled up with sediment since $>35 \mathrm{ka}$ until ca. $11 \mathrm{ka} \mathrm{BP}$, when the moraine dam was breached, the lake was drained and incorporated to the fluvial network (Salazar-Rincón et al., 2013).

During the Holocene, the glaciers in the Marboré Cirque were confined to the southern half of the cirque, with ice masses associated with the large wall at the northern face of the Monte Perdido Massif (composed of the Monte Perdido, Cilindro and Marboré peaks). These glaciers undoubtedly experienced numerous spatial fluctuations (Fig. 7), following patterns similar to those seen for other Holocene glaciers in mountain massifs of the world during the climate changes experienced since the beginning of the Holocene (e.g. Mayewski et al., 2004; Deline and Orombelli, 2005; Camborieu Nebout et al., 2009; Clague et al., 2009; Davis et al., 2009; Menounos et al., 2009; Nesje, 2009; Bakke et al., 2010; Wanner et al., 2011). Davis et al. (2009) concluded that many alpine glaciers disappeared during the Early Holocene, as temperatures warmed, particularly between 7 and $5.5 \mathrm{ka}$ (Holocene Thermal Optimum) (Holzhauser et al., 2005; Wanner et al., 2011; Renssen et al., 2012; Geirsdóttir et al., 2013). Many of such glaciers appeared again during the Neoglacial period (Davis et al., 2009; Kelly and Lowell, 2009; Geirsdóttir et al., 2013). In addition, the relatively large extent of the LIA glaciers probably obscured most of the previous Holocene-era deposits (Deline and Orombelli, 2005). Figure 8 presents two geomorphic transects showing the relative positions of the glacial deposits and the rock avalanche, as well as the dates obtained from our analysis of cosmogenic exposure ages. The extents of the glaciers in the Mid Holocene and during the LIA are also indicated. A general view of the Marboré Cirque is presented in Fig. 9, showing the location of the LIA glaciers, the rock avalanche and the Neoglacial moraine.

Two of the deposits found in the Marbore Cirque, the rock avalanche and the outermost moraine, are related to processes that occurred before the LIA, according to our ${ }^{36} \mathrm{Cl}$ dating. Although we have only a single boulder dated from the moraine $(5.1 \pm$ $0.1 \mathrm{ka}$ ) this is the first Holocene date for glacial deposits in the Iberian Peninsula, apart from those of the LIA. Notably, radiocarbon ages from the Troumouse Cirque, located 9 $\mathrm{km}$ to the north on the French side of the Pyrenees, revealed an intensification of glacial activity between $5190 \pm 90 \mathrm{yr}$ BP and $4654 \pm 60 \mathrm{yr}$ BP (Gellatly et al., 1992), with glaciers larger than those developed during the LIA. This period coincides with the end of the relatively more humid and warmer conditions during the early Holocene to mid 
Holocene and the onset of a trend towards more arid and (most probably) colder conditions around 5-4.5 ka detected in the Marboré Lake (Oliva-Urcia et al., 2013) and a significant lake-level drop in other lakes in the Pyrenees after 5.7 cal yr BP (PérezSanz et al., 2013). In Sierra Nevada, southern Spain, this Mid-Holocene cold period coincided with the development of solifluction landforms (Oliva and Gómez Ortiz, 2011). This era was also characterized by the development of rock glaciers in the Pyrenees (Serrano et al., 2011) and the Cantabrian Range of northern Spain (Pellitero et al., 2011).

This period of glacial advance has also been reported in many other mountain areas. For instance, Mayewski et al. (2004) stated that the most extensive of the socalled Holocene Rapid Climate Changes occurred from 6000 to $5000 \mathrm{yr}$ BP. In the Alps, a generalized advance of the glaciers occurred during the period 5350-4900 yr BP in most regions (Denton and Karlén,1973; Haas et al., 1998; Deline and Orombelli, 2005; Joerin et al., 2006; Wanner et al., 2011), with some exceptions (Ivy-Ochs et al., 2009a). Nesje (2009) reported several glacial advances in Scandinavia, including one at 56005300 yr BP. A short-lived cooling event was detected by Dormoy et al. (2009) in the Alboran and Aegean seas at 6.0-5.5 yr BP. A millennial-scale glacier advance was also identified in Western Canada by Clague et al. (2009) at 6.9-5.6 ka, and by Maurer et al. (2012) at 5.4-4.9 ka (the so-called Garibaldi Phase). Davis et al. (2009) confirmed that glaciers reformed and/or advanced in many regions of the world during the Neoglacial period, starting at approximately $6.5 \mathrm{ka}$. In general, this cold period coincided with an arid phase in the Western Mediterranean (Jalut et al., 2000, 2009).

No evidence of older Holocene glacial activity has been found in the Marboré Cirque. The 8.2 Event (Alley and Agutsdottir, 2005) has been detected in some Pyrenean lake records (Sanz-Pérez et al., 2013), and it had remarkable consequences for human activity and settlements in some parts of the Mediterranean region (GonzálezSampériz et al., 2009). However, it was likely too short-lived to have large consequences on alpine glacier dynamics. Sediment cores from the Marboré Lake do not reflect any significant depositional change during the 8.2 Event (Oliva-Urcia et al., 2013).

The ${ }^{36} \mathrm{Cl}$ age that we obtained for the outermost moraine appears to contradict the geomorphological evidence from other deposits and the dates obtained for polished bedrock using the same method. This is the case for the avalanche of grey limestone boulders $(2.5 \pm 0.05 \mathrm{ka}$ and $4.4 \pm 0.1 \mathrm{ka})$ located a bit further away from the Monte 
Perdido Wall, as well as the polished surfaces $(3.4 \pm 0.2 \mathrm{ka}$ and $2.5 \pm 0.1 \mathrm{ka})$, located in the Central Threshold. This apparent contradiction may reflect technological limitations when using cosmogenic methods to date the exposure ages of limestone surfaces, which may be easily dissolved in a snowy environment. Nevertheless, ${ }^{36} \mathrm{Cl}$ dating has been applied successfully to the limestone surfaces of archaeological remnants, when combined with adequate corrections for the snow cover and high dissolution rate (10 $\mathrm{mm} \mathrm{ka-1}$ ) (Ivy-Ochs et al., 2009b). The intense dissolution of limestone could potentially explain why we obtained more recent dates for the avalanche deposit than for the outermost moraine, and could account for the dating differences between the two boulders sampled from the avalanche. However, even if we apply a dissolution rate of $20 \mathrm{~mm} \mathrm{ka}^{-1}$, the dates would remain too recent, at 2.4 and $4.1 \mathrm{ka}$. An alternative explanation is that the avalanche boulders underwent a rapid transport with fragmentation that facilitated subsequent erosion and weathering. In spite of these uncertainties, these minimal ages indicate that the avalanche occurred during the Holocene, prior to the LIA.

The ages obtained from the polished bedrocks of the Central Threshold date the time when the ice retreated from these surfaces, but they are also difficult to integrate in the general glaciation framework for the Holocene. It is noteworthy that the glacial advances during Neoglaciation reflected periods of sudden, short climate change, and our dating method is not precise enough to distinguish the glaciation and deglaciation dates. However, the existence of clear glacial striations indicates that there was minimal post-glacial erosion, confirming that the deglaciation was a recent event. One possibility is that the polished bedrock was covered by other deposits, but we do not have any geomorphological evidence of such deposition. Another possibility is that these surfaces were covered by a glacier prior to the LIA. This possibility is more consistent with our observations, especially given that the Central Threshold was not, but almost fully glaciated during the LIA, when the Equilibrium Line Altitude was located somewhat below $2700 \mathrm{~m}$ (i.e. slightly below the $2750-\mathrm{m}$ summits of the Central Threshold). Thus, a glacial advance slightly more intense than that experienced during the LIA would have developed a small icefield over the Central Threshold during this period (3.5-2.5 $\mathrm{ka})$.

If we accept the above hypothesis, the ages obtained for the surface-polished bedrock of the Central Threshold indicate that a glacier retreated between $3.4 \pm 0.2 \mathrm{ka}$ and $2.5 \pm 0.1 \mathrm{ka}$ coinciding with the Bronze-Iron Ages. This coincides with the end of 
one of the most important glacial advances of the Neoglacial period, at 3.5-2.3 ka (Mayewski et al., 2004; Wanner et al., 2008, 2011; Davis et al., 2009). This advance could have glaciated the summit of the Central Threshold, where the two sampling sites were located. Consistent with this, important glacial advances around 3.5-3.2 and 2.62.4 ka have been detected in the Alps (Haas et al., 1998; Deline and Orombelli, 2005; Holzhauser et al., 2005; Joerin et al., 2006; Ivy-Ochs et al., 2009a), Scandinavia (Nesje, 2009; Bakke et al., 2010), Iceland (Larsen et al., 2012; Geirsdóttir et al., 2013), the Altai Mountains (Chernykh et al., 2013), West Greenland (Levy et al., 2013), West Canada (Tiedeman-Peyto Advance) (Clague et al., 2009; Menounos et al., 2009; Maurer et al., 2012) and the Sierra Nevada of California (Bowerman and Clark, 2011). This is typically considered a period of minimum glaciation (Holzhauser et al., 2005) due to increasing aridity in the Pyrenees (Pérez-Sanz et al., 2013), the Iberian Peninsula (Martín-Puertas et al., 2008) and the Western Mediterranean in general (Nieto-Moreno et al., 2011). However, more humid conditions have been found in some other areas (Menounos et al., 2009; Corella et al., 2011; Moreno et al., 2011). For example, the sedimentary record from the Laguna de la Mosca in Sierra Nevada (southern Spain) indicates that a glacier was present at the northern face of the Mulhacén Peak between 2.8-2.7 ka BP (Oliva and Gómez Ortiz, 2012).

Another polished surface was also dated in a small depression of the Central Threshold $(1.2 \pm 0.1 \mathrm{ka})$, suggesting the presence of a glacier during the generalized glacial expansion that took place between 1.4-1.2 ka (Dark Age Cold Period) in Europe and North-America (Mayewski et al., 2004; Bakke et al., 2010; Wanner et al., 2008, 2011; Menounos et al., 2009; Davis et al., 2009; Nesje, 2009; Larsen et al., 2012; Maurer et al., 2012; Chernykh et al., 2013; Geirsdóttir et al., 2013; Levy et al., 2013; Lowell et al., 2013). The glaciation of this phase equaled (Haas et al., 1998; Ivy-Ochs et al., 2009a) and in some cases surpassed (Holzhauser et al., 2005; Deline and Orombelli, 2005) the LIA glacier advance in some areas of the Alps. Furthermore, glaciation reappeared on the northern slope of Mulhacén Peak (Sierra Nevada, southern Spain), between 1.4-1.2 ka BP (Oliva and Gómez Ortiz, 2012). The age of this polished surface indicates that during the Medieval Climatic Anomaly (MCA, 1.15-0.65 cal ky BP) deglaciation occurred at the high altitudes in the Pyrenees. The MCA was warmer and relatively more arid period in the Iberian Peninsula as indicated by lacustrine records from NE Spain (Morellón et al., 2012; Corella et al., 2012, 2013), and southern Spain (Zoñar and La Moska lakes: Martín-Puertas et al., 2008; Oliva and Gómez Ortiz, 2012), 
marine sediment near the Alboran basin (Martín-Puertas et al., 2010; Nieto-Moreno et al., 2011), and fossil pollen data from southern France to southeast Spain (Jalut et al., 2000). According to Moreno et al. (2012), the MCA in the Iberian Peninsula was characterized by decreased lake levels, fewer floods, major Saharan aeolian fluxes, and less fluvial input to marine basins.

A new and far-reaching glacial re-advance occurred during the LIA (Fig. 7), a period of relatively colder and more humid conditions in the Iberian Peninsula, but with large climate variability (Morellón et al., 2012). Numerous fluctuations in the sizes of the ice masses in the Marboré Cirque demonstrate that the glaciers expanded and contracted following small climate changes. During the LIA maximum extent, the glaciers almost fully contacted with the mid Holocene outermost moraine. The LIA moraines are very well defined, with acute ridges composed of blocks embedded in a massive fine matrix. The largest of these moraines developed at the foot of the Monte Perdido Peak, resulting in a frontal-lateral deposit that extended to the east. Later, a retreat followed by a new (probably short-lived) expansion caused a re-advance during which the ice mass covered the previous moraines, leaving deposits in the form of fluted moraines (Martín Moreno, 2004; González Trueba et al., 2008). Since then, the region has experienced intense deglaciation, particularly in the middle of the 19th century and the end of the 20th century: the Western and Central glaciers have melted, and the Monte Perdido Glacier has become an increasingly thin ice mass. Until the middle of the 20th century, the Monte Perdido Glacier consisted of three stepped ice masses. The lowest one, which was supported by snow and ice avalanches from the intermediate glacier, had already melted in the late 1970s. The other two ice masses have been in a rapid regressive stage since the 1980s, decreasing in both area and (especially) thickness. The intermediate glacier formed an abrupt ice cliff that produced frequent ice avalanches. It had a bevelled ice front that lost up to $40 \mathrm{~m}$ in thickness between 1981 and 1999 (Julián and Chueca, 2007) (Fig. 10). According to Chueca and Julián (2010, published in 2011) and considering the location of the LIA moraines, the glaciers of the Marboré Cirque occupied 239 ha at the end of the LIA, 62.1 ha in 1999, and only 49.2 ha in 2011.

In the Lake Glacier, deglaciation caused the rapid development of gelifraction, solifluction and nivation processes, leading to the disappearance of glacial landforms under a series of debris cones. Patterned ground also developed in small flat areas, mainly in the eastern sector of the Marboré Lake and in some platforms of the Central 
Threshold, close to the western end of the cirque (Boyé, 1952b). Other glaciers have also disappeared over the last few decades, including those in the southern versant of the Monte Perdido Massif (i.e., Soum de Ramond, Southwest Cilindro and South Taillón) and other Pyrenean massifs (Chueca et al., 2002).

González Trueba et al. (2008) confirmed that the maximum LIA glacier advance occurred at the end of the 17 th or the beginning of the 18th centuries, coinciding with the Maunder Minimum (a period of low sunspot activity, 1645-1715 AD) (Morellón et al., 2012). This maximum has also been supported by dendrochronological data (Saz and Creus, 2001). However, lichenometric analyses dated the maximum advance between 1600 and 1620 yr BP in the Maladeta Massif (Julián and Chueca, 1998).

Another significant advance may have occurred during the Dalton Minimum (1790-1830 AD), according to the field descriptions of Ramond de Carbonnières (1801, $1803,1813)$. In any case, the glacier fronts were in contact with or very close to the moraines of the maximum in 1873 (Schrader, 1874). Many glaciers worldwide had their maximum Holocene expansions during the first half of the 19th century, as documented in Scandinavia (Nesje, 2009; Bakke et al., 2012), Iceland (Larsen et al., 2012; Geirsdóttir et al., 2013), some parts of Greenland (Kelly and Lowell, 2009; Lowell et al., 2013), some glaciers in Western Canada (Menounos et al., 2009; Maurer et al., 2012), Sierra Nevada of California (Bowerman and Clark, 2011), and many other mountains of the Northern Hemisphere (Wanner et al., 2008). In the Alps, the most generalized maximum advance during the Holocene occurred in 1850-1860 (Ivy-Ochs et al., 2009a), when the expansion in some places surpassed the advance of the Maunder Minimum (Haas et al., 1998; Holzhauser et al., 2005; Deline and Orombelli, 2005).

Although generalized glacial retreat started after this phase in the Pyrenees, some Pyrenean glaciers experienced a minor re-advance during a short cooling period between 1880 and 1910 (Saz and Creus, 2001). Since the turn of the 20th century, the mean temperature in the southern Pyrenees has increased between 0.85 and $1{ }^{\circ} \mathrm{C}$, as estimated by Chueca et al. (1998), López-Moreno (2000) and González Trueba et al. (2008). Glacial retreat of the 20th century has affected all of the Pyrenean glaciers (Gellatly et al., 1994; López-Moreno, 2000; Chueca Cía et al., 2005), as well as those in the Sierra Nevada, southern Spain (Gómez Ortiz et al., 2004) and the Cantabrian Range (González Trueba et al., 2008). Strong and rapid glacial retreats in response to climate warming have also been reported throughout the Alps, particularly in the case of small glaciers (Diolaiuti et al., 2011). Chueca Cía et al. (2005) demonstrated that the retreat of 
the Pyrenean glaciers is related to increases in annual temperature and decreases in winter precipitation, and not to summer temperature or the annual precipitation. It is also noteworthy that the late-spring snow accumulation in the Pyrenees has shown a significant negative trend since the mid 20th century, due to a progressive decline in winter precipitation (López-Moreno, 2005).

\section{Conclusions}

The Marboré Cirque contains the best examples of Holocene glacial deposits in the Iberian Peninsula. A detailed geomorphological survey of the different deposits and new cosmogenic dates on surface exposure allow us to reconstruct the Holocene glacial evolution with the following phases:

(i) Deglaciation of most of the Marboré Cirque occurred before 12.7 cal. ky BP.

(ii) There is no evidence of glacial activity during the Early Holocene. It is highly probable that some ice masses persisted at the foot of the northern face of the Monte Perdido Massif, but their moraines have been obscured by subsequent glacial advances. Thus, as seen for many other mountains worldwide, the early Holocene glaciers in this region were much smaller than those of the mid Holocene or LIA.

(iii) A glacial expansion occurred during the Mid Holocene (5.1 $\pm 0.1 \mathrm{ky} \mathrm{BP})$, and a large continuous push moraine was generated by a unique ice mass at the foot of the Monte Perdido Massif.

(iv) A large rock avalanche occurred during the Mid Holocene, affecting the northern face of the Monte Perdido Peak and leaving a chaotic deposit of large grey limestone blocks. This avalanche has not yet been related to any environmental event.

(v) The surface exposure ages of approximately $3.4 \pm 0.2$ and $2.5 \pm 0.1 \mathrm{ky} \mathrm{BP}$ shows a glacial retreat synchronous with the Bronze/Iron Ages, following one of the most important glacial advances of the Neoglacial period.

(vi) A melting period occurred during the MCA (ca. $1.2 \pm 0.1 \mathrm{ka}$ ) after a small glacial expansion during the Dark Age Cold Period (1.4-1.2 ka).

(vii) The LIA represented a clear stage of glacial expansion, with independent ice masses expanding from the bases of the Monte Perdido, Cilindro and Marboré peaks. Two different pulses were separated by a short retraction. The first (more extended) pulse most likely occurred at the end of the 17th century or the beginning of the 18th century (Maunder Minimum), whereas the second, which appears to have occurred between 1790 and 1830 (Dalton Minimum), was a rapid glacial advance that left only 
thin deposits as fluted moraines. Since then, glaciers have been receding rapidly, particularly during the second half of the 20th century.

\section{Acknowledgements}

This work was supported by HORDA (ref: 83/2009), funded by the Organismo Autónomo de Parques Nacionales, and by INDICA (CGL2011-27753-C02-01 and -02) and CGL2012-35858, funded by the Spanish Ministry of Economy and Competitiveness. Financial support for the Research Group on Geomorphology and Global Change was provided by the Aragón Government and the European Social Fund (ESF-FSE).

\section{References}

Alley RB and Agutsdottir AM (2005) The $8 \mathrm{k}$ event: cause and consequences of a major Holocene abrupt climate change. Quaternary Science Reviews 24: 1123-1149.

Bakke J, Dahl SO, Paasche O et al. (2010) A complete record of Holocene glacier variability at Austre Okstindbreen, northern Norway: an integrated approach. Quaternary Science Reviews 29: 1246-1262.

Bonaparte R (1891) Les variations périodiques des glaciers francais. Annuaire du Club Alpin Francais, 18: 3-40.

Bond G, Showers W, Cheseby M et al. (1997) A pervasive millennial-scale cycle in North Atlantic Holocene and glacial climates. Science 278: 1257-1266.

Bowerman ND and Clark DH (2011) Holocene glaciation of the central Sierra Nevada, California. Quaternary Science Reviews 30: 1067-1085

Boyé M (1952a) Névés et érosion glaciaire. Revue de Géomorphologie Dynamique 3 : 20-36.

Boyé M (1952b). Gélivation and cryoturbation dans le massif du Mont-Perdu (Pyrénées Centrales). Pirineos 23: 5-25

Camborieu Nebout N, Peyron O, Dormoy I et al. (2009) Rapid climatic variability in the west Mediterranean during the last 25,000 years from high resolution pollen data. Climate of the Past 5: 503-521.

Chernykh DV, Galakhov V and Zolotov DV (2013) Synchronous fluctuations of glaciers in the Alps and Altai in the second half of the Holocene. The Holocene 23: 1074-1079. DOI: 10.1177/0959683612475143. 
Chueca J, Julián A (2010) Dinámica de los glaciares del Pirineo aragonés: resultados de la campaña glaciológica del año 2011. Boletín Glaciológico Aragonés 11: 9-183.

Chueca J, Julián-Andrés A and Peña-Monné JL (2002) Comparación de la situación de los glaciares del Pirineo español entre el final de la Pequeña Edad del Hielo y la actualidad. Boletín Glaciológico Aragonés 3: 13-41.

Chueca J, Peña JL, Lampre F et al. (1998) La Pequeña Edad del Hielo en el Pirineo Central meridional: influencias paleoambientales a partir de datos geomorfológicos. In A. Gómez Ortiz A and Pérez Alberti A (eds.) Las huellas glaciares de las montañas españolas, Santiago de Compostela: Universidad de Santiago de Compostela, pp. 307-328.

Chueca Cía J, Julián Andrés A, Saz Sánchez MA et al. (2005) Responses to climatic changes since the Little Ice Age on Maladeta Glacier (Central Pyrenees). Geomorphology 68: 167-182.

Clague JJ, Menounos B, Osborn G et al. (2009) Nomenclature and resolution in Holocene glacial chronologies. Quaternary Science Reviews 28: 2231-2238.

Corella JP, Moreno A, Morellón M et al. (2011) Climate and human impact on a meromictic lake during the last 6,000 years (Montcortès Lake, Central Pyrenees, Spain). Journal of Paleolimnology 46: 351-367.

Corella JP, Brauer A, Mangili C et al. (2012). The $1.5 \mathrm{ka}$ varved record of Lake Moncortés (southern Pyrenees, NE Spain). Quaternary Research 78: 323-332.

Corella JP, Stefanova V, El Anjoumi A. et al. (2013). A 2500-year multi-proxy reconstructionof climate change and human activities in northern Spain: The Lake Arreo record. Palaeogeography, Palaeoclimatology, Palaeoecology 386: 555-568.

Davis PT, Menounos B and Osborn G (2009) Holocene and latest Pleistocene alpine glacier fluctuations: a global perspective. Quaternary Science Reviews 28: 20212033.

Degrange A (1882) Note sur le retrait des glaciers Pyrénées. Annuaire du Club Alpin Francais, 8: 560-579

Del Barrio G, Creus J and Puigdefábregas J (1990) Thermal seasonality of the high mountain belts of the Pyrenees. Mountain Research and Development 10: 227-233.

Del Valle J (1997) La precipitación media anual en el sector alto de la cuenca del Cinca (Pirineo aragonés, España). Pirineos 149-150: 121-144. 
Deline P, Orombelli G (2005) Glacier fluctuations in the western Alps during the Neoglacial, as indicated by the Miage morainic amphitheatre (Mont Blanc massif, Italy). Boreas 34: 456-467.

Denton GH and Karlén W (1973) Holocene climatic variations: their pattern and possible cause. Quaternary Research 3: 155-205.

Diolaiuty GA, Maragno D, D'Agata C et al. (2011) Glacier retreat and climate change: Documenting the last 50 years of Alpine glacier history from area and geometry changes of Dosdè Piazzi glaciers (Lombardy Alps, Italy). Progress in Physical Geography 35: 161-182.

Dormoy I, Peyron O, Combourieu Nebout N et al. (2009) Terrestrial climate variability and seasonality changes in the Mediterranean region between 15000 and 4000 years BP deduced from marine pollen records. Climate of the Past 5: 615-632.

Feuillet T and Mercier D (2012) Post-Little Ice Age patterned ground development on two Pyrenean proglacial areas: from deglaciation to periglaciation. Geografiska Annaler, Series A, Physical Geography 94A: 363-376.

Fletcher WJ, Sánchez Goñi MF, Peyron O et al. (2010) Abrupt climate changes of the last deglaciation detected in a western Mediterranean forest record. Climate of the Past 6: 245-264.

García-Ruiz JM and Martí-Bono C (2001) Mapa geomorfológico del Parque Nacional de Ordesa y Monte Perdido. Madrid: Organismo Autónomo de Parques Nacionales, $106 \mathrm{pp}$.

García-Ruiz JM, Martí-Bono C, Peña-Monné JL et al. (2013) Glacial and fluvial deposits in the Aragón Valley, central-western Pyrenees: Chronology of the Pyrenean Late Pleistocene glaciers. Geografiska Annaler, Series A, Physical Geography 95: 15-32.

Geirsdóttir Á, Miller GH, Larsen DJ et al. (2013) Abrupt Holocene climate transitions in the northern North Atlantic region recorded by synchronized lacustrine records in Iceland. Quaternary Science Reviews 70: 48-62.

Gellatly AF, Grove JM, Bucher A et al. (1994) Recent historical fluctuations of the glacier du Taillon, Pyrenees. Physical Geography 15: 399-413.

Gellatly AF, Grove JM and Switsur VR (1992) Mid-Holocene glacial activity in the Pyrenees. The Holocene 2-3: 266-270.

Gómez de Llarena J (1936) Algunos datos sobre el glaciar actual del Monte Perdido. Boletín de la Real Sociedad Española de Historia Natural 36: 327-343. 
Gómez Ortiz A, Schulte L, Salvador F et al. 2004. Deglaciación reciente de Sierra Nevada. Repercusiones morfogénicas, nuevos datos y perspectivas de estudio futuro. Cuadernos de Investigación Geográfica 30: 147-168.

González Trueba JJ, Martín Moreno R, Martínez de Pisón E et al. (2008) 'Little Ice Age' glaciation and current glaciers in the Iberian Peninsula. The Holocene 18: 551568 .

González-Sampériz P, Utrilla P, Mazo C et al. (2009) Patterns of human occupation during the early Holocene in the Central Ebro Basin (NE Spain) in response to the 8.2 ka climate event. Quaternary Research 71: 121-132.

Gosse JC and Phillips FM (2001) Terrestrial in situ cosmogenic nuclides: theory and application. Quaternary Science Reviews 20 (14): 1475-1560.

Haas JN, Richoz I, Tinner W et al. (1998) Synchronous Holocene climatic oscillations recorded on the Swiss Plateau and at timberline in the Alps. The Holocene 8: 301309.

Hernández-Pacheco E, and Vidal Box C (1946) La tectónica y la morfología del macizo de Monte Perdido y de las zonas de cumbres inmediatas en el Pirineo Central. Pirineos 4: 69-108.

Holzhauser H, Magny M and Zumbühl, H.J (2005) Glacier and lake-level variations in west-central Europe over the last 3500 years. The Holocene 15: 789-801.

Ivy-Ochs S, Kerschner H, Maisch M et al. (2009a) Latest Pleistocene and Holocene glacier variations in the European Alps. Quaternary Science Reviews 28: 2137-2149. Ivy-Ochs S, Poschinger AY, Synal HA et al. (2009b). Surface exposure dating of the Flims landslide, Graubünden, Switzerland. Geomorphology 103: 104-112

Jalut G, Amat AE, Bonnet L et al. (2000) Holocene climatic changes in the Western Mediterranean, from south France to south-east Spain. Palaeogeography, Paleoclimatology, Palaeoecology 160: 255-290.

Jalut G, Dedoubat JJ, Fontugne M et al. (2009) Holocene circum-Mediterranean vegetation changes: climate forcing and human impact. Quaternary International 200: 4-18.

Jiménez-Sánchez M, Rodríguez-Rodríguez L, García-Ruiz JM et al. (2013). A review of glacial geomorphology and chronology in northern Spain: Timing and regional variability during the last glacial cycle. Geomorphology 196: 50-64. 
Joerin UE, Stocker TF and Schlüchter C. (2006). Multi-century glacier fluctuations in the Swiss Alps during the Holocene. The Holocene 16: 697-704.

Julián A and Chueca J (1998) Le Petit Âge Glaciaire dans les Pyrénées Centrales Meridionales: estimation des paléotemperatures à partir d'inferences géomorphologiques. Sud-Ouest Européen 3 : 79-88.

Julián, A., Chueca, J. 2007. Pérdidas de extensión y volumen en los glaciares del macizo de Monte Perdido (Pirineo central español): 1981-1999. Boletín Glaciológico Aragonés 8 : 31-60.

Kelly MA and Lowell TV (2009). Fluctuations of local glaciers in Greenland during latest Pleistocene and Holocene time. Quaternary Science Reviews 28: 2088-2106.

Lal D (1991) Cosmictray labeling of erosion surfaces: in situ production rates and erosion models. Earth and Planetary Science Letters 104: 424-439.

Larsen D, Miller GH, Geirsdóttir Á et al.. (2012) Non-linear Holocene climate evolution in the North Atlantic: a high-resolution, multi-proxy record of glacier activity and environmental change from Hvítárvatn, central Iceland. Quaternary Science Reviews 39: 14-25.

Levy LB, Kelly MA, Lowell TV et al. (2013) Holocene fluctuations of Bregne ice cap, Scoresby Sund, east Greenland: a proxy for climate along the Greenland Ice Sheet margin. Quaternary Science Reviews. Epub. Ahead of print 1 Augusrt 2013, DOI 10.1016/j.quascirev.2013.06.024

Lewis CJ, McDonald EV, Sancho C et al. (2009) Climatic implications of correlated Upper Pleistocene glacial and fluvial deposits on the Cinca and Gállego rivers (NE Spain) base don OSL dating and soil stratigraphy. Global and Planetary Change 67: $141-152$.

López-Moreno JI (2000) Los glaciares del alto valle del Gállego (Pirineo Central) desde la Pequeña Edad del Hielo. Implicaciones en la evolución de la temperatura. Logroño: Geoforma Ediciones, 77 pp.

López-Moreno JI (2005) Recent variations of snowpack depth in the Central Spanish Pyrenees. Arctic, Antarctic, and Alpine Research 37: 253-260.

Lowell TV, Hall BL, Kelly MA et al. (2013) Late Holocene expansion of Istorvet ice cap, Liverpool Land, east Greenland. Quaternary Science Reviews 63: 128-140 
Magny M, Miramont C and Sivan O (2002) Assessment of the impact of climate and anthropogenic factors on Holocene Mediterranean vegetation in Europe on the basis of palaeohydrological records. Palaeogeography, Palaeoclimatology, Palaeoecology 186: 47-59.

Marcott SA, Shakun JD, Clark PU et al. (2013) A reconstruction of regional and global temperature for the past 11,300 years. Science 339: 1198-1201.

Martí-Bono C and García-Ruiz JM (1993) La extension del glaciarismo cuaternario en el Parque Nacional de Ordesa y Monte Perdido. Geographicalia 30: 271-282.

Martín Moreno R (2004) Comparación de dos glaciares: Longyearbreen (Spitsbergen) y Monte Perdido (Pirineos). Características y evolución desde la Pequeña Edad del Hielo. Ería 63: 5-22.

Martín-Puertas C, Jiménez-Espejo F, Martínez-Ruiz F et al. (2010) Late Holocene climate variability in the southwestern Mediterranean region: an integrated marine and terrestrial geochemical record. Climate of the Past 6: 807-816.

Martín-Puertas C, Valero-Garcés BL, Mata MP et al. (2008) Arid and humid phases in southern Spain during the last 4000 years: the Zoñar Lake record, Córdoba. The Holocene 18: 907-921.

Martínez de Pisón E, and Arenillas Parra M (1988) Los glaciares actuales del Pirineo español. In: Ministerio de Obras Públicas y Urbanismo (ed.) La nieve en el Pirineo español. Madrid: Ministerio de Obras Públicas y Urbanismo, pp. 29-98.

Maurer K, Menounos B, Luckman BH et al. (2012) Late Holocene glacier expansion in the Cariboo and northern Rocky Mountains, British Columbia, Canada. Quaternary Science Reviews, 51: 71-80

Mayewski PA, Rohling EE, Stager JC et al. (2004) Holocene climate variability. Quaternary Research 62: 243-255.

Médiathéque de l'Architecture et du Patrimoine, (1890, 1910). Photo collection about Marboré Cirque. Ministère de la Culture et de la Communication, République Francaise. Available at: http://www.mediatheque-patrimoine.culture.gouv.fr/

Menounos B Osborn G, Clague JJ et al. (2009) Latest Pleistocene and Holocene glacier fluctuations in western Canada. Quaternary Science Reviews 28: 2049-2074.

Morellón M, Pérez-Sanz A, Corella JP et al. (2012) A multi-proxy perspective on millennium-long climate variability in the southern Pyrenees. Climate of the Past 8: 683-700. 
Moreno A, López-Merino L, Leira M et al. (2011) Revealing the last 13,500 years of environmental history from the multiproxy record of a mountain lake (Lago Enol, northern Iberian Peninsula). Journal of Paleolimnology 46: 327-349.

Moreno A, Pérez A, Frigola J et al. (2012) The medieval climate anomaly in the Iberian Peninsula reconstructed from moraine and lake records. Quaternary Science Reviews 43: 16-32.

Nesje A (2009) Latest Pleistocene and Holocene alpine glacier fluctuations in Scandinavia. Quaternary Science Reviews 28: 2119-2136.

Nicolás Martínez P (1981) Morfología del circo de Tucarroya (Macizo de Monte Perdido, Pirineo aragonés). Cuadernos de Investigación Geográfica 7 (1-2): 51-80.

Nieto-Moreno V, Martínez-Ruiz F, Giralt S et al. (2011) Tracking climate variability in the western Mediterranean during the Late Holocene: a multiproxy approach. Climate of the Past 7: 1395-1414.

Oliva-Urcia B, Moreno A, Valero-Garcés B et al. (2013) Magnetismo y cambios ambientales en registros terrestres: el lago de Marboré, Parque Nacional de Ordesa y Monte Perdido (Huesca). Cuadernos de Investigación Geográfica 39 (1): 117-140.

Oliva M and Gómez Ortiz A (2011) Holocene slope dynamics in Sierra Nevada (south Spain). Sedimentological analysis of solifluction landforms and lake deposits. Geological Society, London, Special Publications 354: 227-239.

Oliva M and Gómez-Ortiz A (2012) Late Holocene environmental dynamics and climate variability in a Mediterranean high mountain environment (Sierra Nevada, Spain) inferred from lake sediments and historical sources. The Holocene 22: 915927.

Pellitero R, Serrano E, and González Trueba JJ (2011) Glaciares rocosos del sector central de la montaña cantábrica: indicadores paleoambientales. Cuadernos de Investigación Geográfica 37 (2): 119-144.

Penck A (1883) La période glaciaire dans les Pyrénées. Bulletin de la Société d'Histoire Naturelle de Toulouse 19: 105-200.

Pérez-Sanz A, González-Sampériz P, Moreno A et al. (2013) Holocene climate variability, vegetation dynamics and fire regime in the central Pyrenees: the Basa de la Mora sequence (NE Spain). Quaternary Science Reviews 73: 149-169.

Phillips FM (2003) Cosmogenic ${ }^{36} \mathrm{Cl}$ ages of Quaternary basalt flows in the Mojave Desert, California, USA. Geomorphology 53: 199-208. 
Phillips FM and Plummer MA (1996) CHLOE: a program for interpreting in-situ cosmogenic nuclide data for surface exposure dating and erosion studies. Radiocarbon 38: 98-99.

Phillips FM, Stone WD and Fabryka-Martin JT (2001) An improved approach to calculating low-energy cosmic-ray neutron fluxes near the land/atmosphere interface. Chemical Geology 175: 689-701.

Ramond de Carbonnières LF (1801) Voyages au Mont-Perdu et dans la partie adjacente des Hautes-Pyrénées. Paris, Chez Belin.

Ramond de Carbonnières LF (1803) Voyage au sommet du Mont-Perdu. Lu à I'Institut le 19 floréal an 11, Journal des Mines, ou Recueil de Mémoires sur l'exploitation des Mines, et sur les Sciences et les Arts 83: 321-350.

Ramond de Carbonnières LF (1813) Travels in the Pyrenees, containing a Description of the Principal Summits, Passes and Vallies, translated from French by F. Gold, London: Longman, Hurst, Ree, Orme and Browne. London.

Renssen H, Seppä H, Crosta X et al. (2012) Global characterization of the Holocene Thermal Maximum. Quaternary Science Reviews 48: 7-19.

Salazar-Rincón A, Mata-Campo P, Rico-Herrera MT (2013) El paleolago de La Larri (Valle de Pineta, Pirineos): Significado en el contexto del último máximo glaciar en el Pirineo. Cuadernos de Investigación Geográfica 39 (1): 97-116.

Saz MA and Creus J (2001) El clima del Pirineo centro-oriental desde el siglo XV: estudio dendroclimático del observatorio de Capdella. Boletín Glaciológico Aragonés 2: 37-79.

Schrader F (1874) Carte du Mont-Perdu et de la Région Calcaire des Pyrénées. Expart des Mémories de la Societé des Sciences Physiques et Naturelles de Bordeaus. Bordeaux: Imp. G. Chariol.

Schrader F (1882-1892) Carte des Pyrénées Centrales à 1/100.000. Club Alpin Francais and Touring Club de France. Paris: Girard et Barrère.

Schrader F (1894) Sur l'étendue des glaciers des Pyrénées. Annuaire du Club Alpin Francais, 21: 403-423..

Schrader F (1914) Massif de Gavarnie et du Mont Perdu. Club Alpin Francais. Paris: Impr. Erhard Fres. 
Serrano E, González Trueba JJ and Sanjosé JJ (2011) Dinámica, evolución y estructura de los glaciares rocosos en los Pirineos. Cuadernos de Investigación Geográfica 37 (2): 145-170.

Stone JOH, Evans JM, Fifield LK et al. (1998) Cosmogenic chlorine-36 production in calcite by muons. Geochimica et Cosmochimica Acta 62: 433-454.

Trutat E (1982) Lac de Marboré. Photo from the colection of the "Bibliotèque de Toulouse". http://www.bibliotheque.toulouse.fr/

Wanner H, Beer J, Bütikefer J et al. (2008) Mid- to Late Holocene climate change: an overview. Quaternary Science Reviews 27: 1791-1828.

Wanner H, Solomina O, Grosjean M et al. (2011) Structure and origin of Holocene cold events. Quaternary Science Reviews 30: 3109-3123.

Zreda M, England J, Phillips F et al. (1999) Unblocking of the Nares Strait by Greenland and Ellesmere icesheet retreat 10,000 years ago. Nature 398: 139-142. 


\section{FIGURE CAPTIONS}

Figure 1 . The study area.
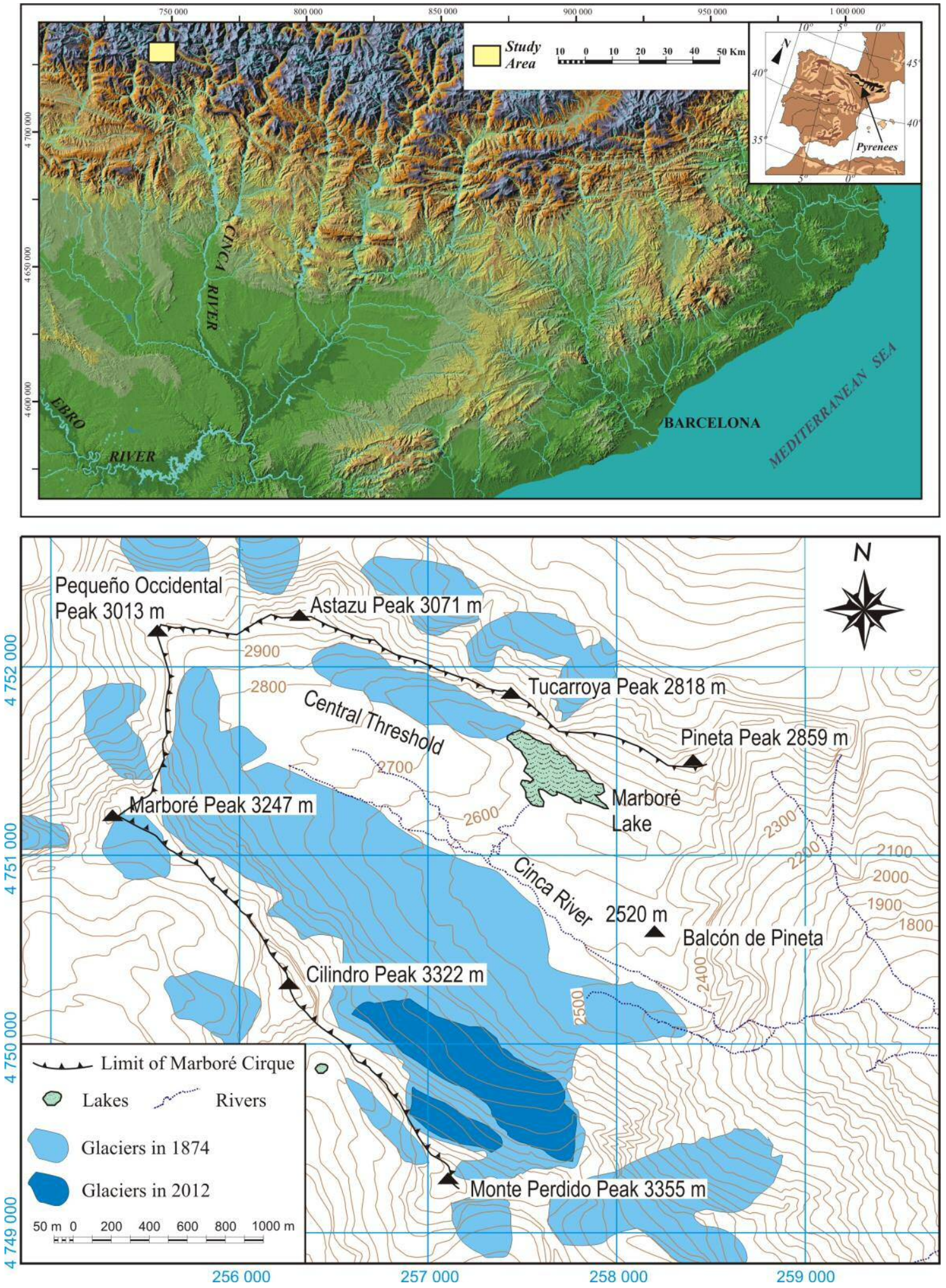
Figure 2. Moraines and other deposits in the Marboré Cirque.

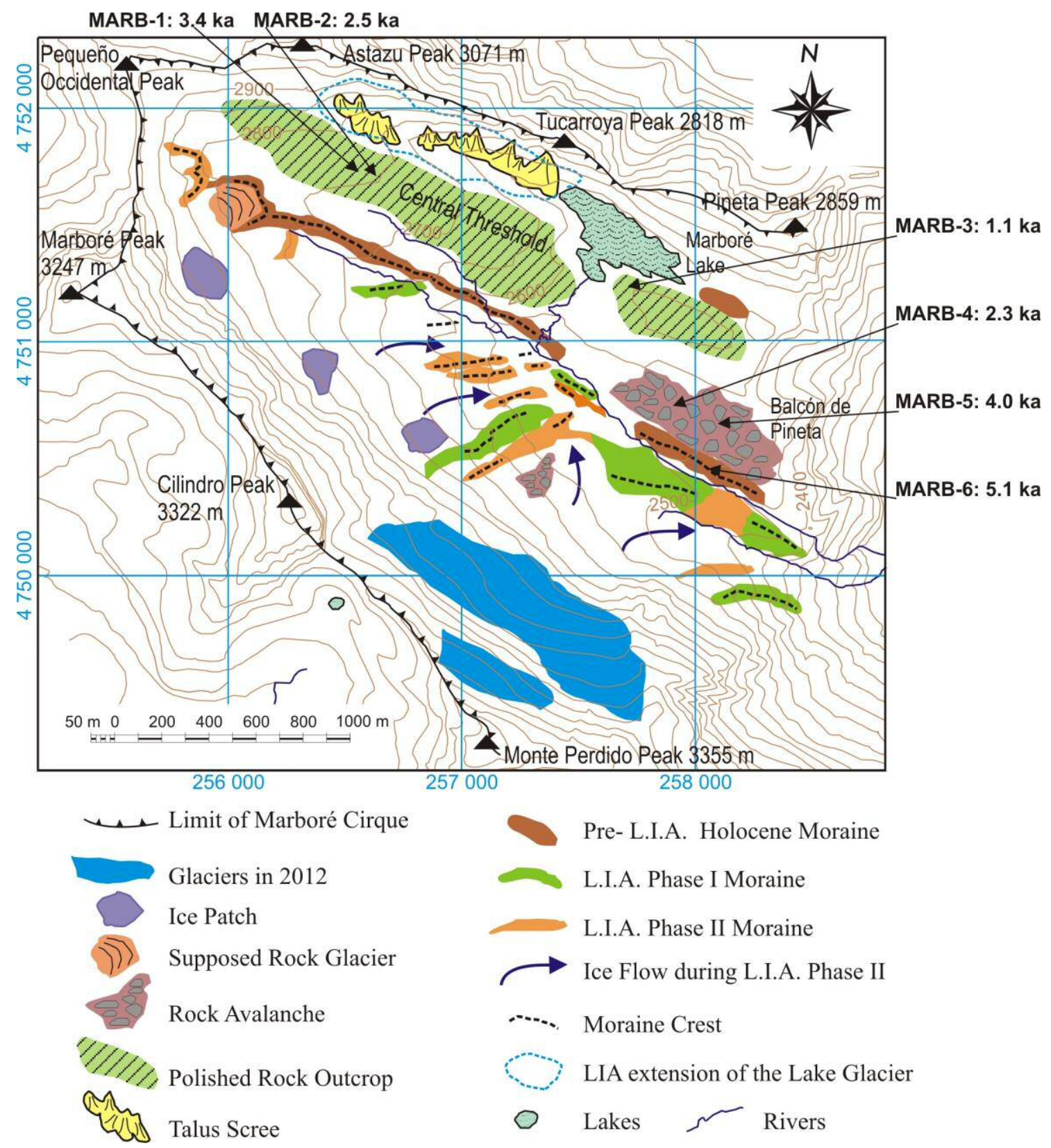


Figure 3. Rock avalanche, composed of large limestone blocks, close to Balcón de Pineta.

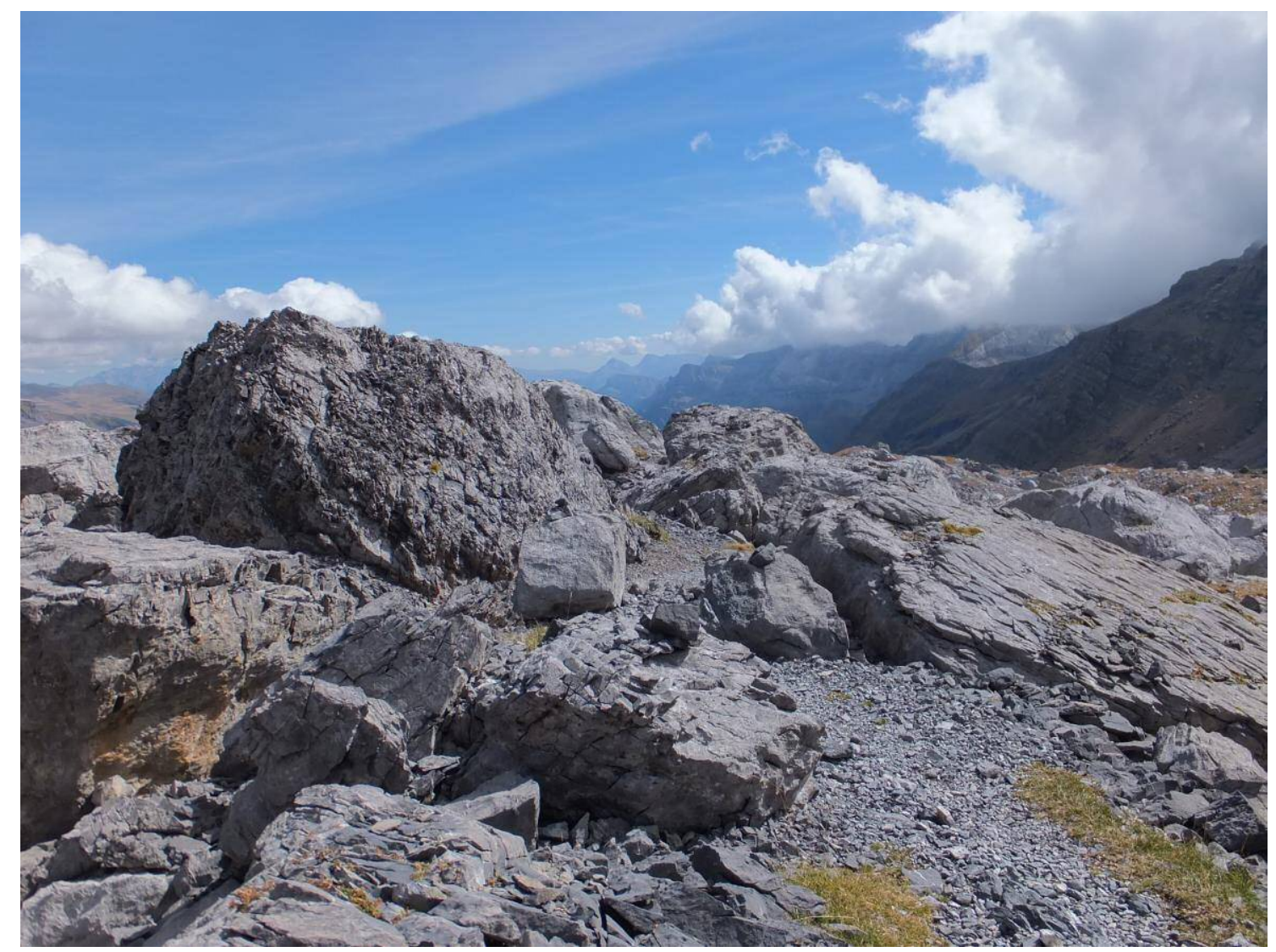


Figure 4. The large outer moraine and the Monte Perdido Peak, with small glaciers remaining at its wall.

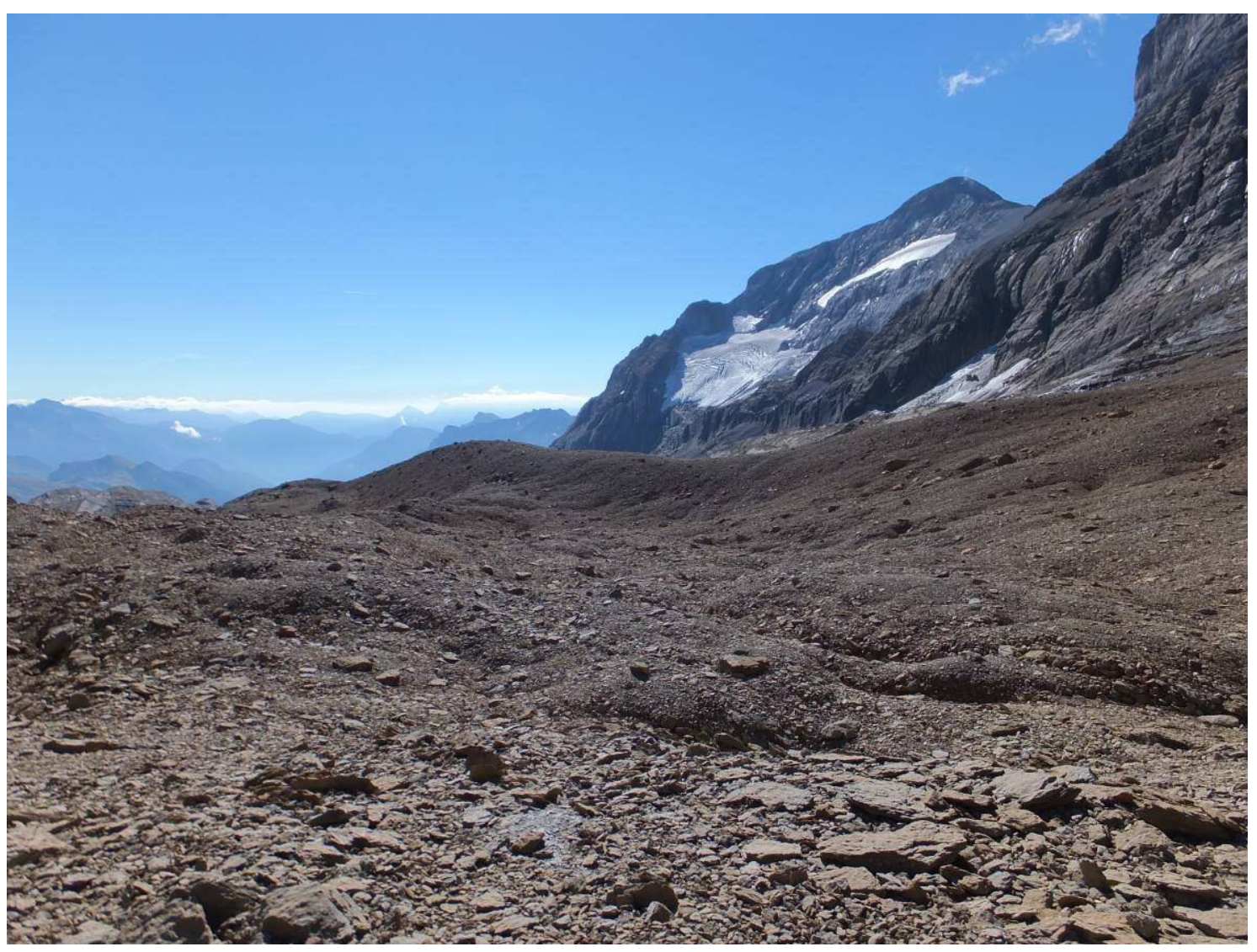


Figure 5. The Monte Perdido Moraine (LIA Moraine), forming a large hill at the foot of the Monte Perdido Glacier. The foreground shows the chaotic accumulation of large limestone blocks and the outer Neoglacial moraine.

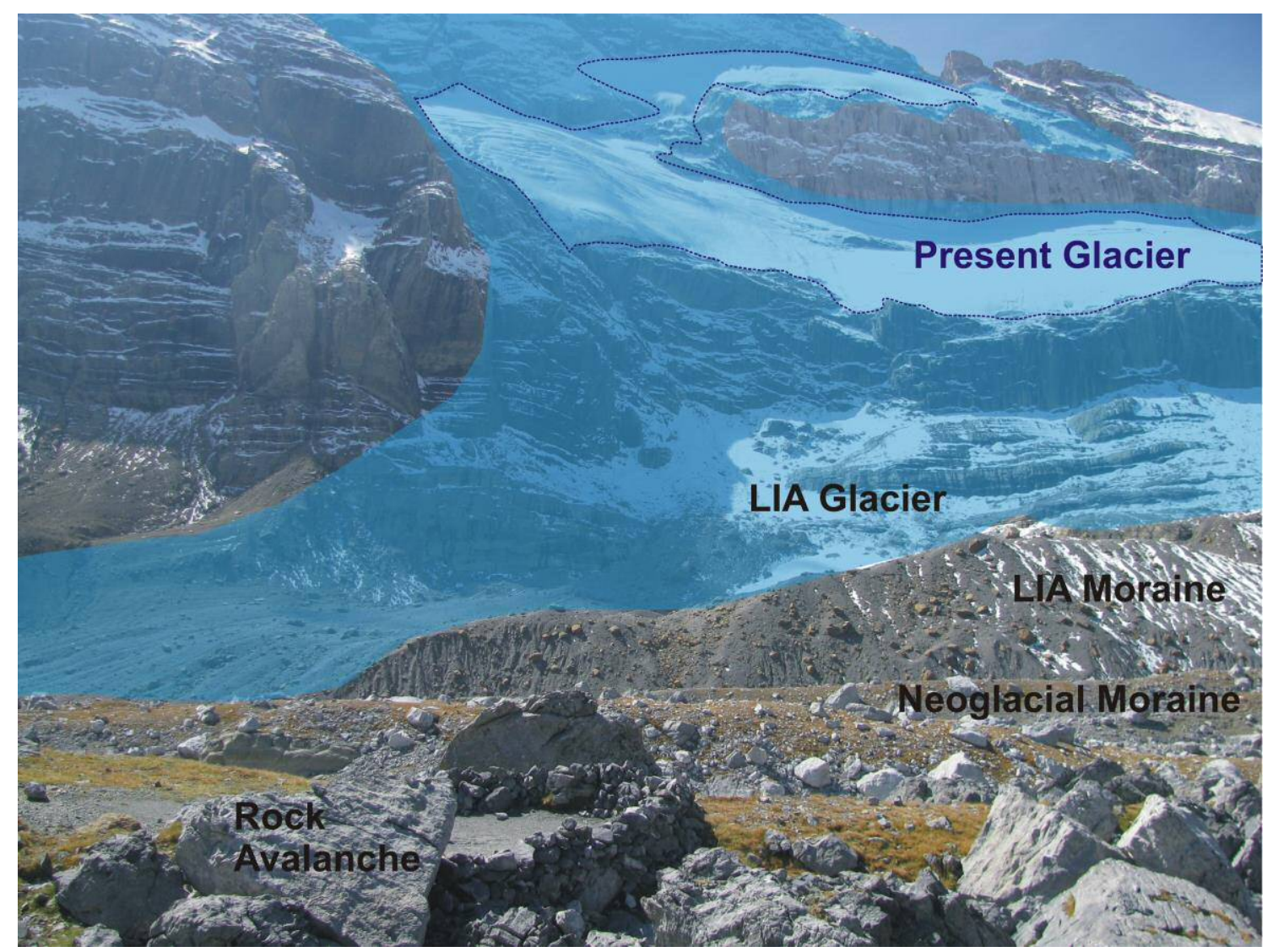


Figure 6. A polished surface sampled for cosmogenic dating of surface exposure near the former location of the Lake Glacier.

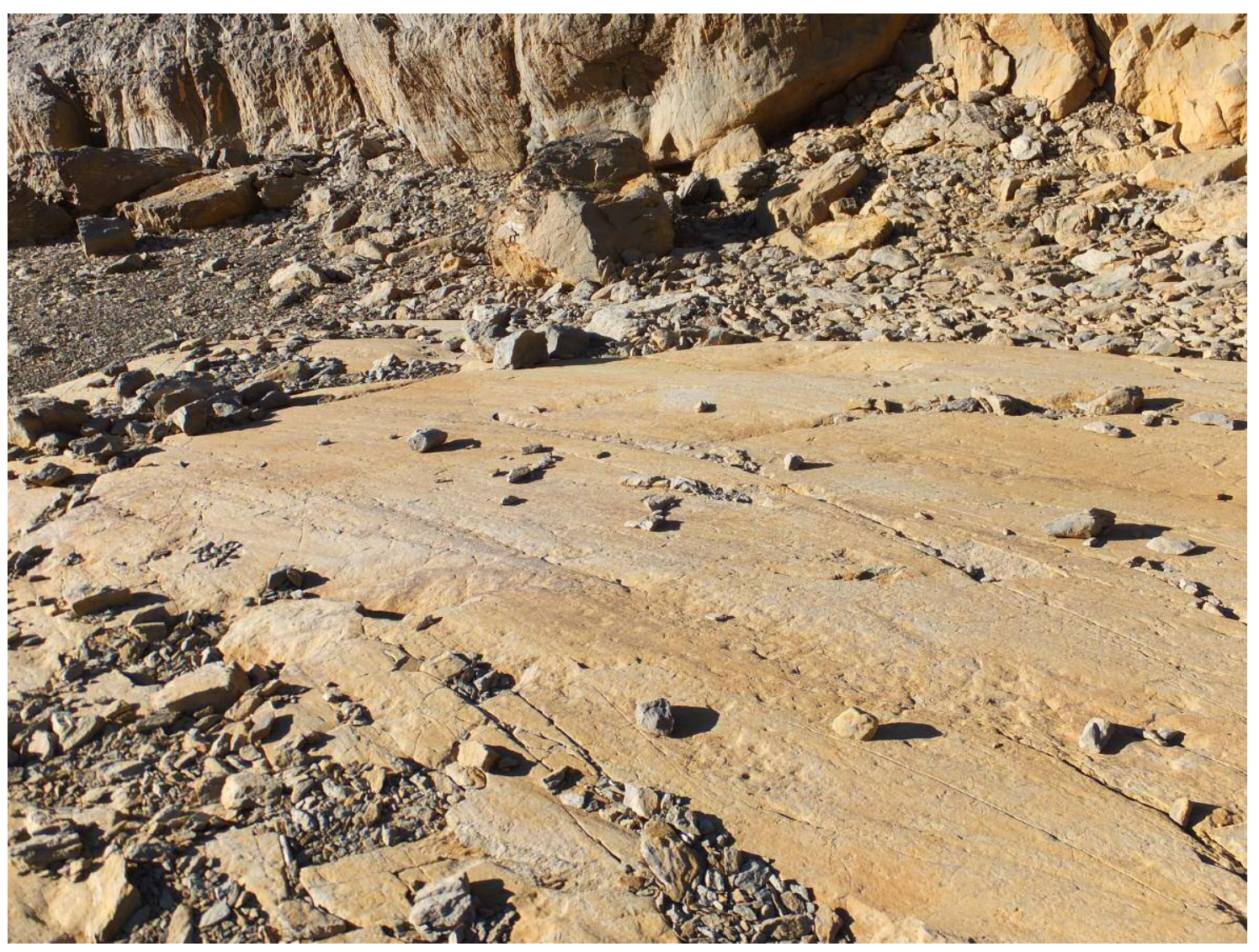

Figure 7. Evolution of glaciers in the Marboré Cirque during the Holocene. (i) Mid Holocene glaciers; (ii) 17-18th century glaciers; and (iii) mid 19th century glaciers. 


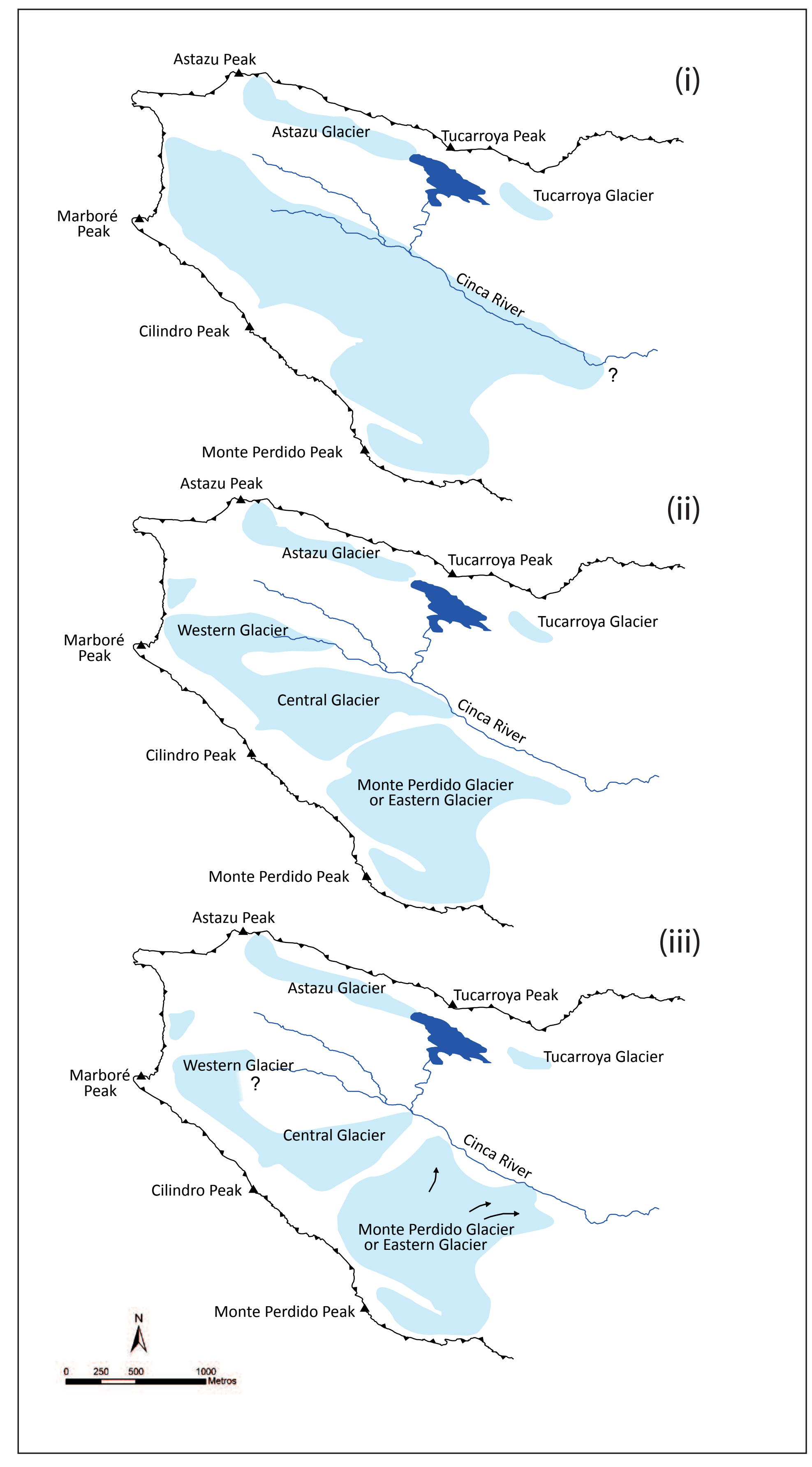


Figure 8. Geomorphic transects taken from the Marbore Cirque, showing the location of glaciers, tills, and the Central Threshold. The locations and surface extent of the Holocene and LIA glaciers are shown.

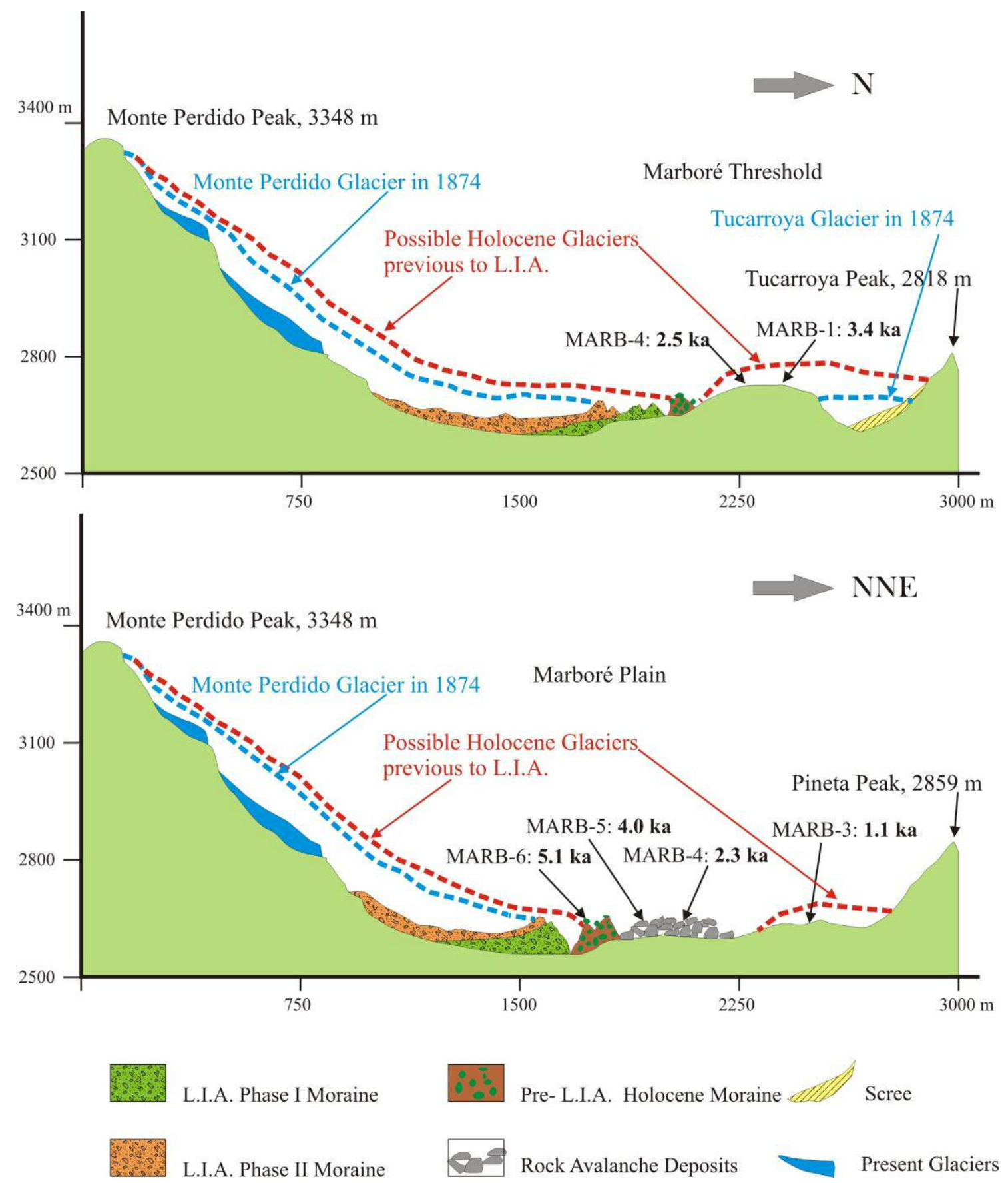


Figure 9. A general view toward the west of the Marbore Cirque, with the position and extent of the LIA glaciers, the rock avalanche and, in the foreground, the Neoglacial, mid-Holocene Moraine.

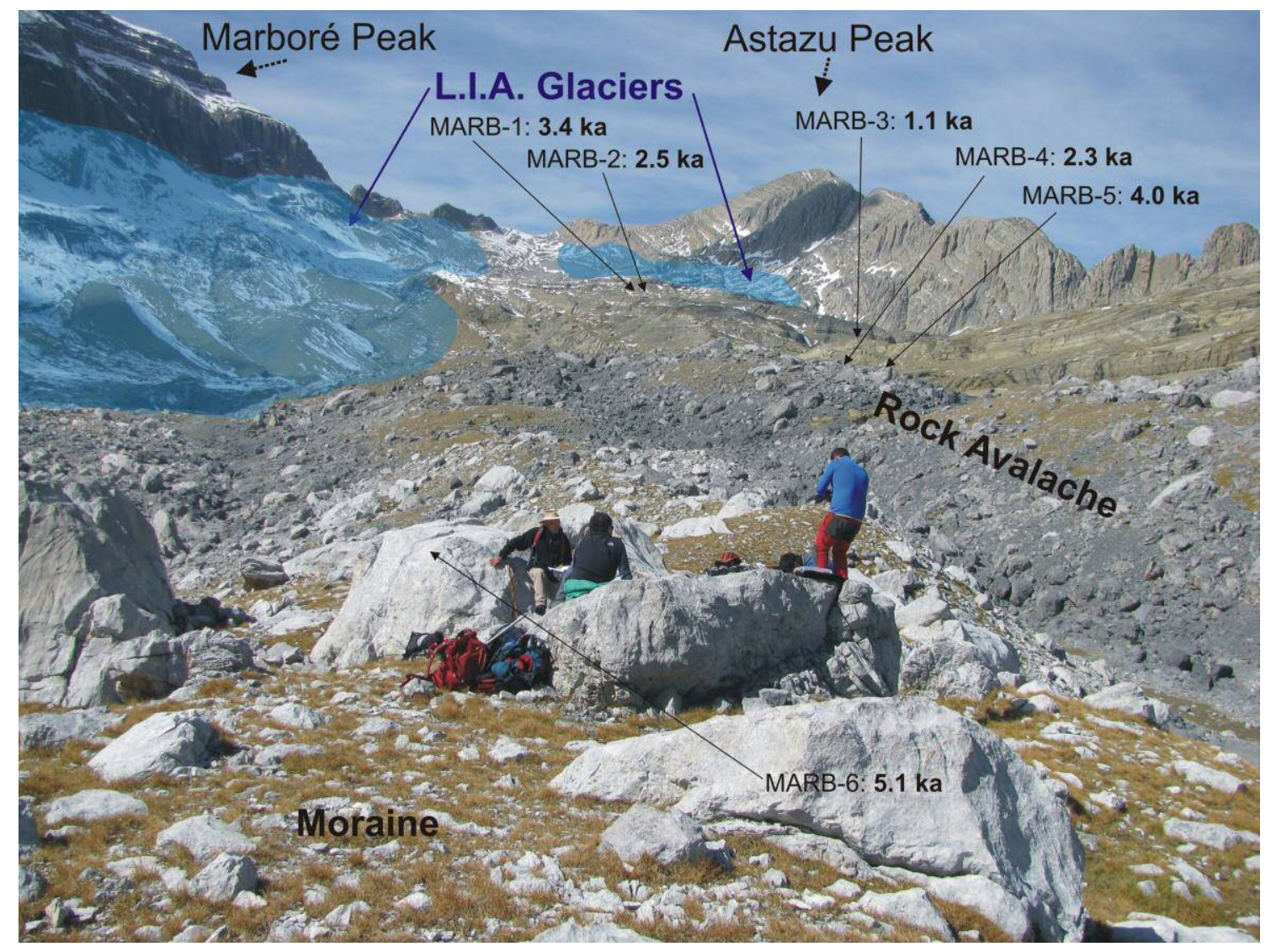


Figure 10. The Upper and Middle (now Lower) Monte Perdido glaciers, showing the bevelled ice surface. The ice masses are located on structural perched flats of the northern face of the Monte Perdido Peak.

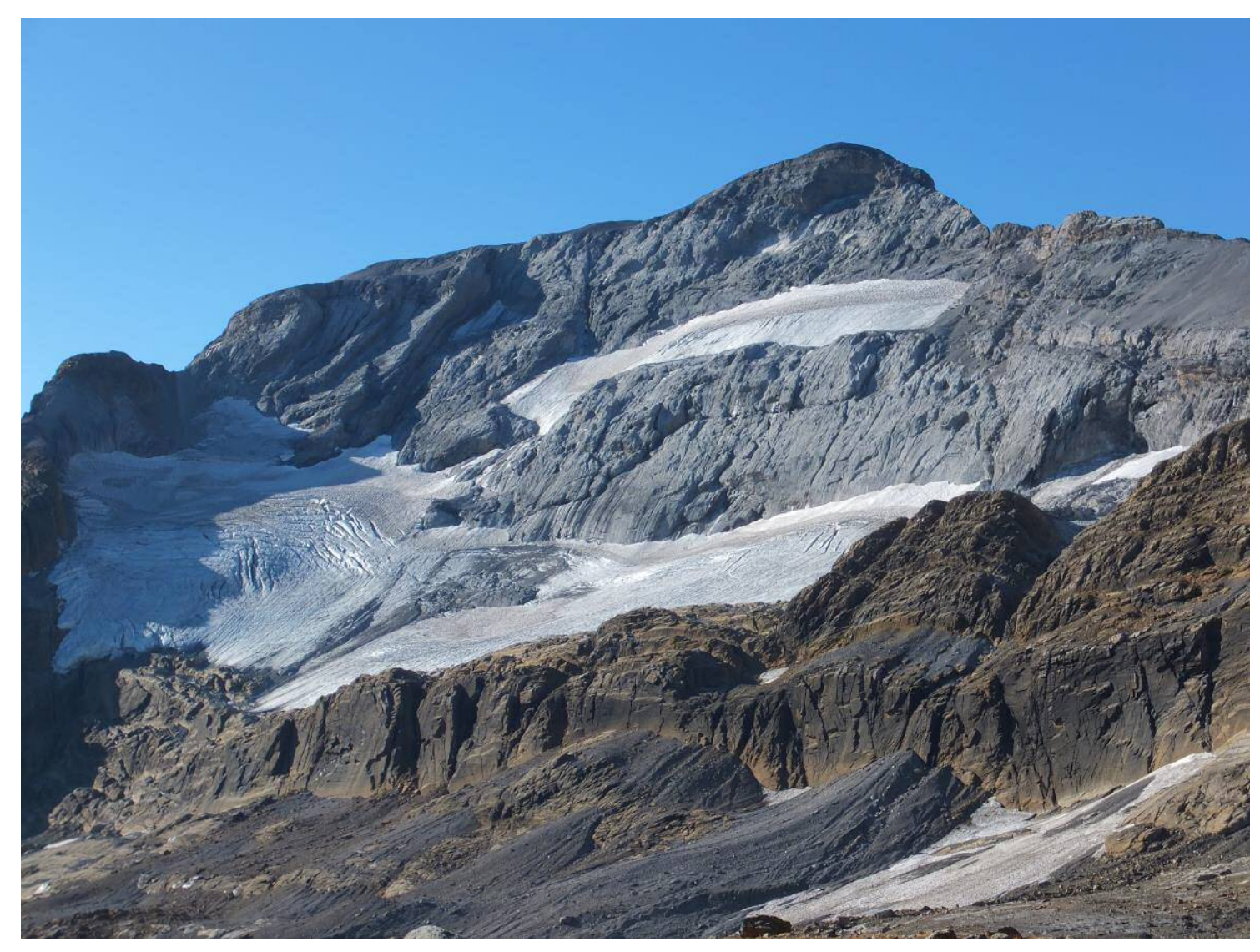

Table I. Grain-size distribution of the fine fraction in the moraines of the Marbore Cirque (\%)

\begin{tabular}{lccccl}
\hline Sample site & $\mathbf{C O}_{\mathbf{3}} \mathbf{C a}$ & Sand & Silt & Clay & Class \\
\hline Outer moraine & 30.2 & 59.9 & 19.9 & 20.1 & Sandy clay loam \\
Mt Perdido main moraine & 86.6 & 55.4 & 7.3 & 37.3 & Sandy clay \\
Cilindro inner moraine & 35.8 & 70.2 & 13.6 & 16.2 & Sandy loam \\
\hline
\end{tabular}




\begin{tabular}{|c|c|c|c|c|c|c|c|c|}
\hline Sample & Sample type & $\begin{array}{l}\text { Zero erosion age } \\
\qquad(\mathrm{ka})\end{array}$ & $\begin{array}{c}1 \mathrm{~mm} / \mathrm{kyr} \text { age } \\
(\mathrm{ka})\end{array}$ & $\begin{array}{c}3 \mathrm{~mm} / \mathrm{ky} \text { r age } \\
(\mathrm{ka})\end{array}$ & $\begin{array}{c}5 \mathrm{~mm} / \mathrm{kyr} \text { age } \\
(\mathrm{ka})\end{array}$ & $\begin{array}{l}\text { Latitude } \\
\left({ }^{\circ} \mathrm{N}\right)\end{array}$ & $\begin{array}{l}\text { Longitude } \\
\quad\left({ }^{\circ} \mathrm{E}\right)\end{array}$ & $\begin{array}{l}\text { Elevation } \\
\text { (m) }\end{array}$ \\
\hline MARB-1 & polished bedrock & $3.4 \pm 0.2$ & $3.4 \pm 0.2$ & $3.7 \pm 0.2$ & $3.7 \pm 0.2$ & $42^{\circ} 41^{\prime} 53.07^{\prime \prime}$ & $0^{\circ} 01^{\prime} 38.73 \prime$ & 2756 \\
\hline MARB -2 & polished bedrock & $2.5 \pm 0.1$ & $2.5 \pm 0.1$ & $2.5 \pm 0.1$ & $2.5 \pm 0.1$ & $42^{\circ} 41^{\prime} 53.37 \prime$ & $0^{\circ} 01 ' 38.38^{\prime \prime}$ & 2756 \\
\hline MARB -3 & polished bedrock & $1.1 \pm 0.1$ & $1.1 \pm 0.1$ & $1.1 \pm 0.1$ & $1.1 \pm 0.1$ & $42^{\circ} 41^{\prime} 35.80^{\prime \prime}$ & $0^{\circ} 02^{\prime} 24.09^{\prime \prime}$ & 2580 \\
\hline MARB -4 & rockslide boulder & $2.3 \pm 0.04$ & $2.3 \pm 0.04$ & $2.3 \pm 0.04$ & $2.3 \pm 0.04$ & $42^{\circ} 41^{\prime} 23.22^{\prime \prime}$ & $0^{\circ} 02^{\prime} 38.69^{\prime \prime}$ & 2542 \\
\hline MARB - 5 & rockslide boulder & $4.0 \pm 0.1$ & $4.0 \pm 0.1$ & $4.0 \pm 0.1$ & $4.0 \pm 0.1$ & $42^{\circ} 41^{\prime} 21.72^{\prime \prime}$ & $0^{\circ} 02^{\prime} 44.72 ”$ & 2544 \\
\hline MARB -6 & moraine boulder & $5.1 \pm 0.1$ & $5.2 \pm 0.1$ & $5.2 \pm 0.1$ & $5.2 \pm 0.1$ & $42^{\circ} 41^{\prime} 16.00^{\prime \prime}$ & $0^{\circ} 02^{\prime} 46.80^{\prime \prime}$ & 2513 \\
\hline
\end{tabular}

Table $2 .{ }^{36} \mathrm{Cl}$ exposure ages, sample type and sample location. Ages are reported for four assumed erosion rates (0, 1, 3, and 5 $\mathrm{mm} / \mathrm{kyr}$ ). Errors correspond to the analytical uncertainty of the AMS ${ }^{36} \mathrm{Cl}$ determination (one standard deviation). 
Table 2. Field and analytical data for ${ }^{36} \mathrm{Cl}$ samples from Marboré, Pyrenees.

\begin{tabular}{|c|c|c|c|c|c|c|c|}
\hline Sample ID & & MARB-1 & MARB -2 & MARB-3 & MARB-4 & MARB-5 & MARB-6 \\
\hline Latitude & $\left({ }^{\circ} \mathrm{N}\right)$ & 42.6981 & 42.6982 & 42.6933 & 42.6898 & 42.7001 & 42.6878 \\
\hline Longitude & $\left({ }^{\circ} \mathrm{E}\right)$ & 0.0274 & 0.0273 & 0.0400 & 0.0333 & 0.0458 & 0.0463 \\
\hline Elevation & (m) & 2756 & 2756 & 2580 & 2542 & 2544 & 2513 \\
\hline Sample thickness & $(\mathrm{cm})$ & 1.5 & 2.5 & 2.5 & 1.5 & 2.0 & 2.0 \\
\hline Shielding factor & (unitless) & 0.798 & 0.798 & 0.831 & 0.947 & 0.974 & 0.964 \\
\hline $\begin{array}{l}\text { Effective fast neutron } \\
\text { attenuation length }\end{array}$ & $\left(\mathrm{g} \mathrm{cm}^{-2}\right)$ & 165 & 165 & 162 & 149 & 171 & 160 \\
\hline $\mathrm{Na}_{2} \mathrm{O}$ & (wt \%) & 0.79 & 0.8 & 0.52 & 0.03 & 0.05 & 0.03 \\
\hline $\mathrm{MgO}$ & (wt \%) & 1.07 & 0.98 & 1.11 & 2.94 & 0.83 & 0.56 \\
\hline $\mathrm{Al}_{2} \mathrm{O}_{3}$ & (wt \%) & 9.81 & 8.94 & 9.04 & 0.48 & 0.58 & 0.14 \\
\hline $\mathrm{SiO}_{2}$ & (wt \%) & 56.23 & 55.46 & 45.75 & 8.55 & 2.75 & 0.38 \\
\hline $\mathrm{P}_{2} \mathrm{O}_{5}$ & (wt \%) & 0.04 & 0.07 & 0.06 & 0.06 & 0.07 & 0.03 \\
\hline $\mathrm{K}_{2} \mathrm{O}$ & (wt \%) & 2.16 & 1.92 & 2.07 & 0.14 & 0.18 & 0.04 \\
\hline $\mathrm{CaO}$ & (wt \%) & 13.97 & 15.06 & 20.83 & 47.31 & 52.98 & 53.69 \\
\hline $\mathrm{TiO}_{2}$ & (wt \%) & 0.649 & 0.628 & 0.468 & 0.041 & 0.025 & 0.004 \\
\hline $\mathrm{MnO}$ & (wt \%) & 0.026 & 0.034 & 0.022 & 0.006 & 0.006 & 0.008 \\
\hline $\mathrm{Fe}_{2} \mathrm{O}_{3}$ & (wt \%) & 3.07 & 2.67 & 2.64 & 0.14 & 0.23 & 0.09 \\
\hline $\mathrm{Cl}$ & (ppm) & 61.70 & 20.19 & 18.19 & 69.93 & 53.62 & 32.62 \\
\hline B & (ppm) & 88.7 & 87.2 & 77.7 & 5.4 & 3.7 & 2.1 \\
\hline Sm & (ppm) & 4.7 & 4.7 & 4.6 & 1 & 0.5 & 0.1 \\
\hline Gd & (ppm) & 4.2 & 4 & 3.8 & 1 & 0.6 & 0.2 \\
\hline U & (ppm) & 3.3 & 3.4 & 3.4 & 2.5 & 1.6 & 0.5 \\
\hline Th & (ppm) & 10.9 & 10.9 & 9 & 1.2 & 0.6 & $<0.1$ \\
\hline${ }^{36} \mathrm{Cl} / \mathrm{Cl}$ ratio (de-spiked) & $\left({ }^{36} \mathrm{Cl} / 10^{15} \mathrm{Cl}\right)$ & 235.7 & 458.5 & 263.7 & 366.0 & 884.0 & 1745.2 \\
\hline $\begin{array}{l}{ }^{36} \mathrm{Cl} / \mathrm{Cl} 1 \sigma \text { uncertainty } \\
\text { (de-spiked) }\end{array}$ & $\left({ }^{36} \mathrm{Cl} / 10^{15} \mathrm{Cl}\right)$ & 14.3 & 16.8 & 16.1 & 6.8 & 18.0 & 28.1 \\
\hline Sample mass & (g) & 27.41 & 25.20 & 29.17 & 26.15 & 28.07 & 25.54 \\
\hline $\begin{array}{l}\text { Mass of }{ }^{35} \mathrm{Cl} \text { spike } \\
\text { solution }\end{array}$ & (mg) & 0.991 & 1.033 & 1.022 & 1.020 & 1.026 & 1.036 \\
\hline $\begin{array}{l}\text { Concentration spike } \\
\text { solution }\end{array}$ & $\left(g g^{-1}\right)$ & 1.0 & 1.0 & 1.0 & 1.0 & 1.0 & 1.0 \\
\hline $\begin{array}{l}\text { Analytical stable isotope } \\
\text { ratio }\end{array}$ & $\left({ }^{35} \mathrm{Cl} /\left({ }^{35} \mathrm{Cl}+{ }^{37} \mathrm{Cl}\right)\right)$ & $5.51 \pm 0.0720$ & $11.25 \pm 0.0200$ & $10.84 \pm 0.1520$ & $5.40 \pm 0.0300$ & $5.90 \pm 0.0230$ & $8.15 \pm 0.0520$ \\
\hline Analytical ${ }^{36} \mathrm{Cl} / \mathrm{Cl}$ ratio & $\left({ }^{36} \mathrm{Cl} / 10^{15} \mathrm{Cl}\right)$ & $147.8 \pm 9.12$ & $149.9 \pm 5.48$ & $89.3 \pm 5.47$ & $233.8 \pm 4.34$ & $522.7 \pm 10.63$ & $772.1 \pm 12.44$ \\
\hline
\end{tabular}

